Supporting Information for:

\title{
A Di-Copper-Peptoid in a Non-Innocent Borate Buffer as a Fast Electrocatalyst for Homogeneous Water Oxidation with Low Overpotential
}

\author{
Guilin Ruan ${ }^{1}$, Pritam Ghosh $^{1}$, Natalia Fridman ${ }^{1}$ and Galia Maayan ${ }^{1,2 *}$ \\ ${ }^{1}$ Schulich Faculty of Chemistry, Technion - Israel Institute of Technology, Technion City, \\ Haifa 32000, Israel. \\ ${ }^{2}$ The Nancy and Stephen Grand Technion Energy Program, Technion - Israel Institute of \\ Technology, Technion City, Haifa 32000, Israel.
}




\section{Experimental Section}

\section{Materials}

Rink Amide resin was purchased from Novabiochem; ethanolamine, and 6-bromo-2,2'-bipyridine were purchased from Acros organics, Israel; $\mathrm{N}, \mathrm{N}$ '-diisopropylcarbodiimide (DIC), bromoacetic acid were purchased from Sigma Aldrich. The other chemicals used in this work have been purchased from commercial sources and used without additional purification. 2-(2,2'-bipyridine-6-yloxy) ethylamine (BPy amine) was prepared according to a literature method ${ }^{1}$ and $-\mathrm{OH}$ group of ethanolamine was protected using a reported procedure. ${ }^{2}$ The used solvents were HPLC grade. High purity deionized water was obtained by passing distilled water through a nanopore Milli-Q water purification system. Aqueous basic buffer solutions at several $\mathrm{pH}$ values were prepared using specific concentrations of boronic acid and sodium tetraborate salts with added $0.2 \mathrm{M}$ $\mathrm{NaOH} / \mathrm{HCl}$ solution such that the final ionic strength equaled to $0.2 \mathrm{M}$.

\section{Instrumentation}

Peptoid oligomers were analyzed by reversed-phase HPLC (analytical C18 column, $5 \mu \mathrm{m}$, $100 \AA, 2.0 \times 50 \mathrm{~mm}$ ) on a Jasco UV-2075 instrument. A linear gradient of 5-95\% ACN in water ( $0.1 \%$ TFA) over $10 \mathrm{~min}$ was used at a flow rate of $0.7 \mathrm{~mL} / \mathrm{min}$. Preparative HPLC was performed using a Phenomenex C18 column $(15 \mu \mathrm{m}, 100 \AA 21.20$ x $100 \mathrm{~mm})$ on a Jasco UV-2075 instrument. Peaks were eluted with a linear gradient of 5-95\% ACN in water $(0.1 \%$ TFA) over $60 \mathrm{~min}$ at a flow rate of $5 \mathrm{~mL} / \mathrm{min}$. Mass spectrometry for peptoids was performed on a Waters LCT Premier mass and Advion expression mass under electrospray ionization (ESI), direct probe $\mathrm{ACN}$ : $\mathrm{H} 2 \mathrm{O}$ (70:30), flow rate $0.2 \mathrm{ml} / \mathrm{min}$. Mass spectrometry for metallopeptoids was performed on a Maxis Impact Bruker Q-TOF mass and Advion expression mass under electrospray ionization (ESI), direct probe $\mathrm{ACN}$ : $\mathrm{H} 2 \mathrm{O}$ (70:30), flow rate $0.5 \mathrm{ml} / \mathrm{min}$. UV-Vis measurements were recorded on an Agilent Technologies Cary 60 UV-Vis spectrophotometer using a $1 \mathrm{~cm}$ path length quartz cuvette. EPR spectra were obtained on a Bruker EMX-10/12 X-band $(v=9.2 \mathrm{GHz})$ digital EPR spectrometer equipped with a Bruker $\mathrm{N}_{2}$ temperature controller. Samples were irradiated with the focused and filtered $(\lambda=300 \mathrm{~nm}$ ) light of high-pressure mercury lamp (1 kW) (ARC lamp power supply model 69920) in the resonator of the EPR spectrometer. All spectra were recorded at a non-saturating microwave power of $200 \mathrm{~mW}, 100 \mathrm{kHz}$ magnetic field modulation of $1 \mathrm{G}$ amplitude. Spectra processing and simulation were performed with a Bruker WIN-EPR and SimFonia Software. The g-factors values were determined using 2,2,6,6- tetramethylpiperidine-N-oxyl (TEMPO) as reference $(\mathrm{g}=2.0058)$. Scanning electron microscopic (SEM) images were taken from TESCAN VEGAII Nanospace instrument. For high resolution scanning electron microscopy (HR-SEM) imaging we used a Zeiss Ultra Plus high-resolution SEM, equipped with a Schottky field-emission gun. Specimens were imaged at low acceleration voltages of $1 \mathrm{kV}$, and working distances of approx. $4 \mathrm{~mm}$. We used the Everhart Thornley ("SE2") secondary electron imaging detector. For confirmation of sample composition, we used a Quantax energy dispersive $\mathrm{x}$-ray spectrometer (EDS, Bruker) at an acceleration voltage of $10 \mathrm{kV}$. 


\section{Preparation and Characterization of Peptoids Oligomers}

The peptoids BEE, BE, BPE were synthesized manually on Rink amide resin using the sub-monomer approach. ${ }^{3}$ Typically, $100 \mathrm{mg}$ of resin was swollen in DCM for 40 minutes at room temperature before initiating oligomer synthesis. Multiple washing steps using DMF were performed between each step described below. De-protection of resin was performed by the addition of $20 \%$ piperidine solution $(0.4 \mathrm{~mL}$ in $1.6 \mathrm{~mL} \mathrm{DMF})$ and the reaction was shaken at room temperature for 20 minutes. Following the reaction, piperidine was washed from the resin using DMF (10 mL/g resin) (3 x 1 minute). Bromo-acetylation was completed by adding 20 equiv. bromoacetic acid (1.2 $\mathrm{M}$ in DMF, $8.5 \mathrm{~mL} / \mathrm{g}$ resin) and 24 equiv. of DIC (diisopropylcarbodiimide) ( $2 \mathrm{~mL} / \mathrm{g}$ resin); this reaction was shaken at room temperature for 20 minutes. Following the reaction, the bromo-acetylation reagents were washed from the resin using DMF (10 mL/g resin) ( $3 \times 1$ minute) and 20 equiv. of submonomer amine (1.0 M in DMF, $10 \mathrm{~mL} / \mathrm{g}$ resin) was added. The amine displacement reactions were shaken at room temperature for 20 minutes except for 2-(2,2'-bipyridine-6-yloxy) ethylamine for 5 hours. The reaction was followed by multiple washing steps (DMF, $10 \mathrm{~mL} / \mathrm{g}$ resin) $(3 \times 1$ minute). Bromo-acetylation and amine displacement steps were repeated until the peptoids were obtained. Following the reaction, the resin was washed by DCM three times and the peptoids were cleaved from the resin by $95 \%$ TFA in water $(40 \mathrm{~mL} / \mathrm{g}$ resin) for 20 minutes. The cleavage cocktail was evaporated in vacuum and the peptoid oligomers were re-suspended in $2 \mathrm{~mL}$ HPLC solvent (1:1 HPLC grade acetonitrile: HPLC grade water) and lyophilized overnight. The peptoids were further purified to $>95 \%$ by RP-HPLC and lyophilized overnight. The peptoids after purification were characterized by analytical HPLC and ESI-MS analysis.

\section{Preparation and Characterization of Metallopeptoid Complexes}

The peptoids $(0.1 \mathrm{mmol})$ were dissolved in methanol $(1 \mathrm{~mL})$, and the mixture was stirred for 10 minutes. This mixture was treated with copper perchlorate hexahydrate $(0.1 \mathrm{mmol}$ as solid) and stirred for 4 hours. A greenish-blue solid precipitate was obtained and was isolated by centrifugation, washed three times with methanol, and dried in vacuum overnight. Then the solid compounds were dissolved in basic borate buffer solution and characterized by X-ray diffraction, UV-Vis, ESI-MS, FTIR, and Raman spectroscopy.

\section{Electrochemical Methods}

Cyclic voltammetry (CV), and differential pulse voltammetry (DPV) experiments were carried out on an EmStat3 potentiostat. Solutions of the complexes were placed in one-compartment three-electrode cells. Glassy Carbon (GC) was used as a working electrode, $\mathrm{Ag} / \mathrm{AgCl}$ as a reference electrode and $\mathrm{Pt}$ wire as a counter electrode. Working electrode pretreatment before each measurement included polishing with $0.05 \mu \mathrm{m}$ alumina paste following by rinsing with water and acetone and finally drying in air. All redox potentials in the present work are reported versus NHE by adding $0.20 \mathrm{~V}$ to the measured potential ( $\mathrm{Ag} / \mathrm{AgCl}$ vs NHE). CVs were collected at $100 \mathrm{mV} / \mathrm{s}$ except for other specifications. DPV was obtained with the following parameters: Amplitude $=200 \mathrm{mV}$, E-step $=10 \mathrm{mV}$, pulse width $=0.01 \mathrm{~s}$. 


\section{Oxygen Evolution Experiment}

Controlled Potential Electrolysis (CPE) experiments were performed using a two-compartment cell closed with septum. Large surface porous carbon (spongy shape) as working electrode together with an $\mathrm{Ag} / \mathrm{AgCl}(\mathrm{NaCl}$ sat.) as reference electrode were placed in one of the compartments that was filled with a $0.5 \mathrm{mM}$ basic buffer solution of the catalyst ( $\mathrm{pH} 9.35$, borate buffer $0.2 \mathrm{M}$ of ionic strength). In the other compartment, containing only the fresh buffer solution, a mesh platinum counter electrode was used. Before starting the experiment, nitrogen gas was purged for $10 \mathrm{~min}$ to remove the oxygen from the system. Oxygen evolution was monitored in the gas phase with a Fixed Needle-Type Oxygen Minisensor (from PyroScience) placed in the headspace of the reaction vassal (working electrode side). The CPE started as soon as the oxygen sensor signal was stable. During the experiment, solutions of both compartments were vigorously stirred. The results of the water oxidation catalysis with copper complex compared with the blank experiment in the same conditions but in the absence of the catalyst. The Faraday efficiency was determined according to the total charge passed during the CPE and the total amount of generated oxygen as a four-electron oxidation process. The oxygen was measured by the oxygen sensor in $\%$ and converted to $\mu \mathrm{mol}$ using a calibration curve. This was constructed by the gradual addition of the known amount of pure oxygen $(\mu \mathrm{L})$ into the cell containing buffer solution using a Hamilton syringe while measuring the oxygen in $\%$ by the oxygen sensor and then by plotting the amount of pure oxygen added $(\mu \mathrm{L})$ vs. the amount of oxygen $(\%)$ shown by oxygen sensor to get the total amount of oxygen evolved in $\mu \mathrm{L}$ during electrolysis (Figure S44). This was further converted to $\mu \mathrm{mol}$ via the equation: $\mathrm{y} \mu \mathrm{mol}=\mathrm{x} \mu \mathrm{L} /(24.5 \mathrm{~L} / \mathrm{mol}), \mathrm{T}=298 \mathrm{~K}$.

Faradaic efficiency (FE\%) was calculated follow below equation:

$$
F E \%=\frac{n_{\mathrm{O}_{2}}}{\frac{Q}{n F}} * 100 \%
$$

Where $n_{\mathrm{O}_{2}}$ is the mole of oxygen from CPE experiment, mol; Q is accumulated charge from CPE experiment, $\mathrm{C} ; \mathrm{n}$ is the number of electrons transferred, 4; $\mathrm{F}$ is Faraday constant, 96485 $\mathrm{C} / \mathrm{mol}$.

Turnover number (TON) was calculated following the below equation:

$$
T O N=\frac{n_{\mathrm{O}_{2}}}{n_{\text {catalyst }}}
$$

Where $n_{\mathrm{O}_{2}}$ is the mole of oxygen from CPE experiment, mol; $n_{\text {catalyst }}$ is the initial mole of catalyst from CPE experiment, mol. 


\section{Supporting Figures}

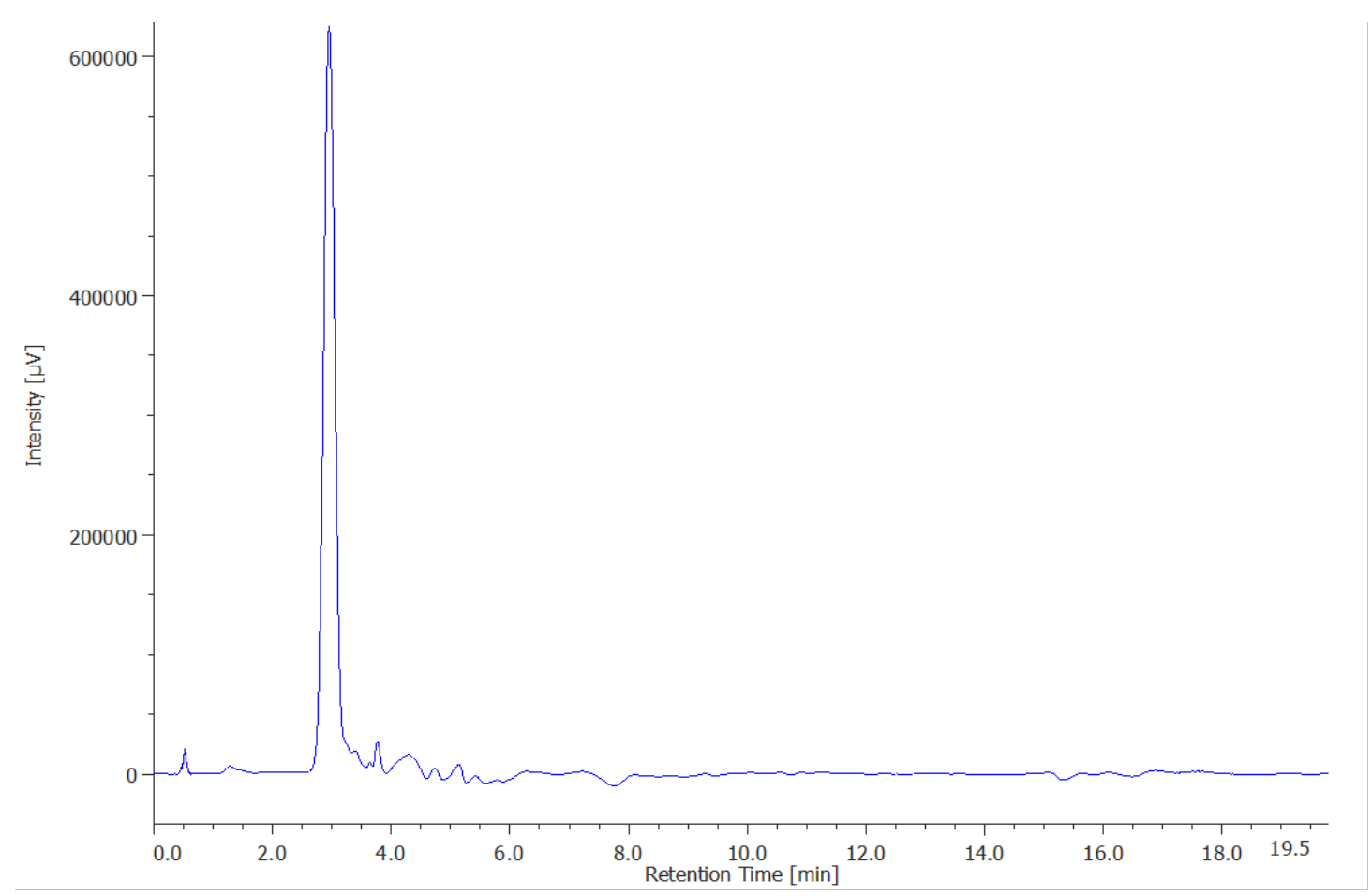

Figure S1. Analytical HPLC of purified peptoid BEE in water/acetonitrile with 0.1\% TFA.

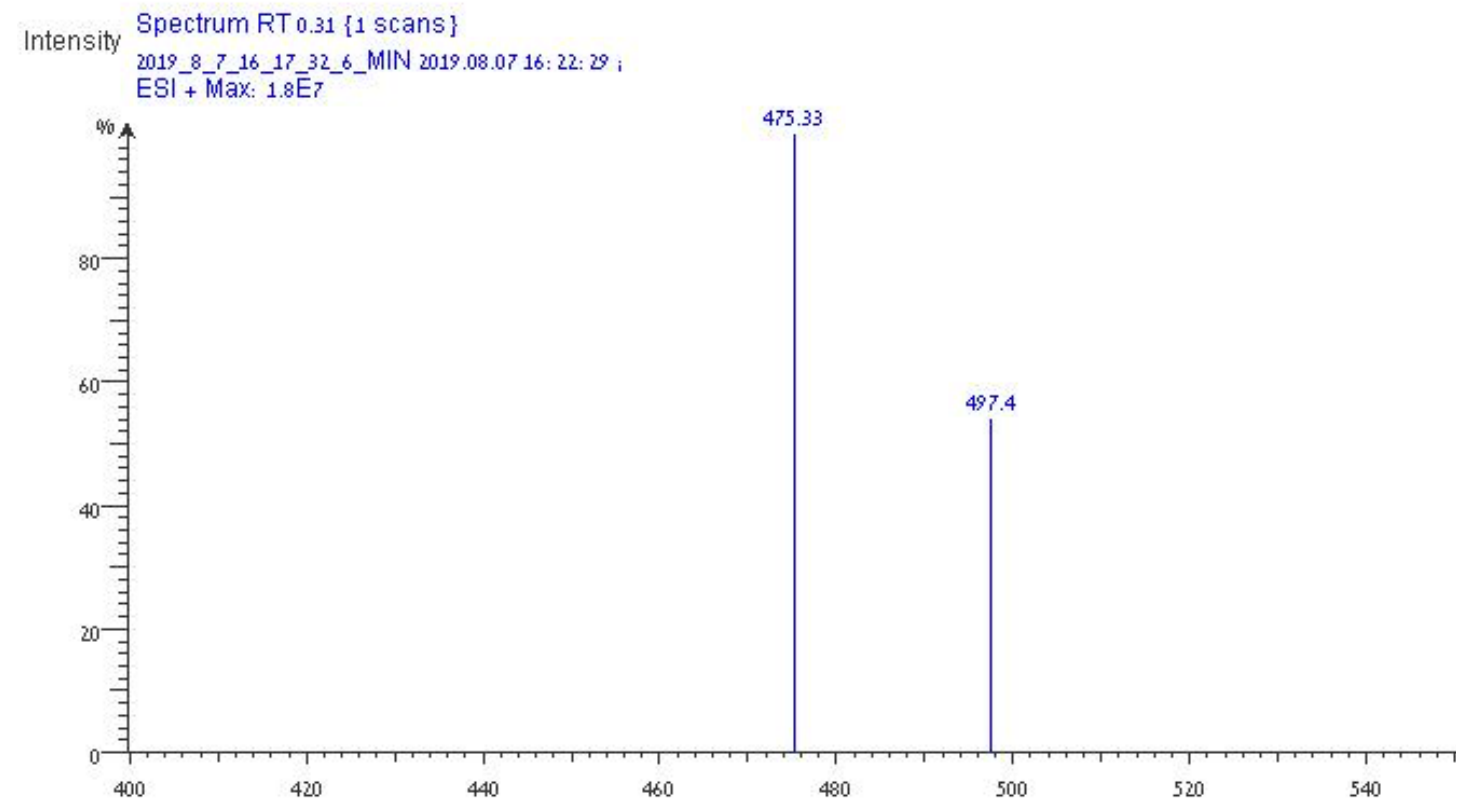

Figure S2. ESI-MS of purified peptoid BEE in water, $\mathrm{m} / \mathrm{z}\left(\mathbf{B E E}+\mathrm{H}^{+}\right)=475.33, \mathrm{~m} / \mathrm{z}(\mathbf{B E E}+$ $\left.\mathrm{Na}^{+}\right)=497.4$. 

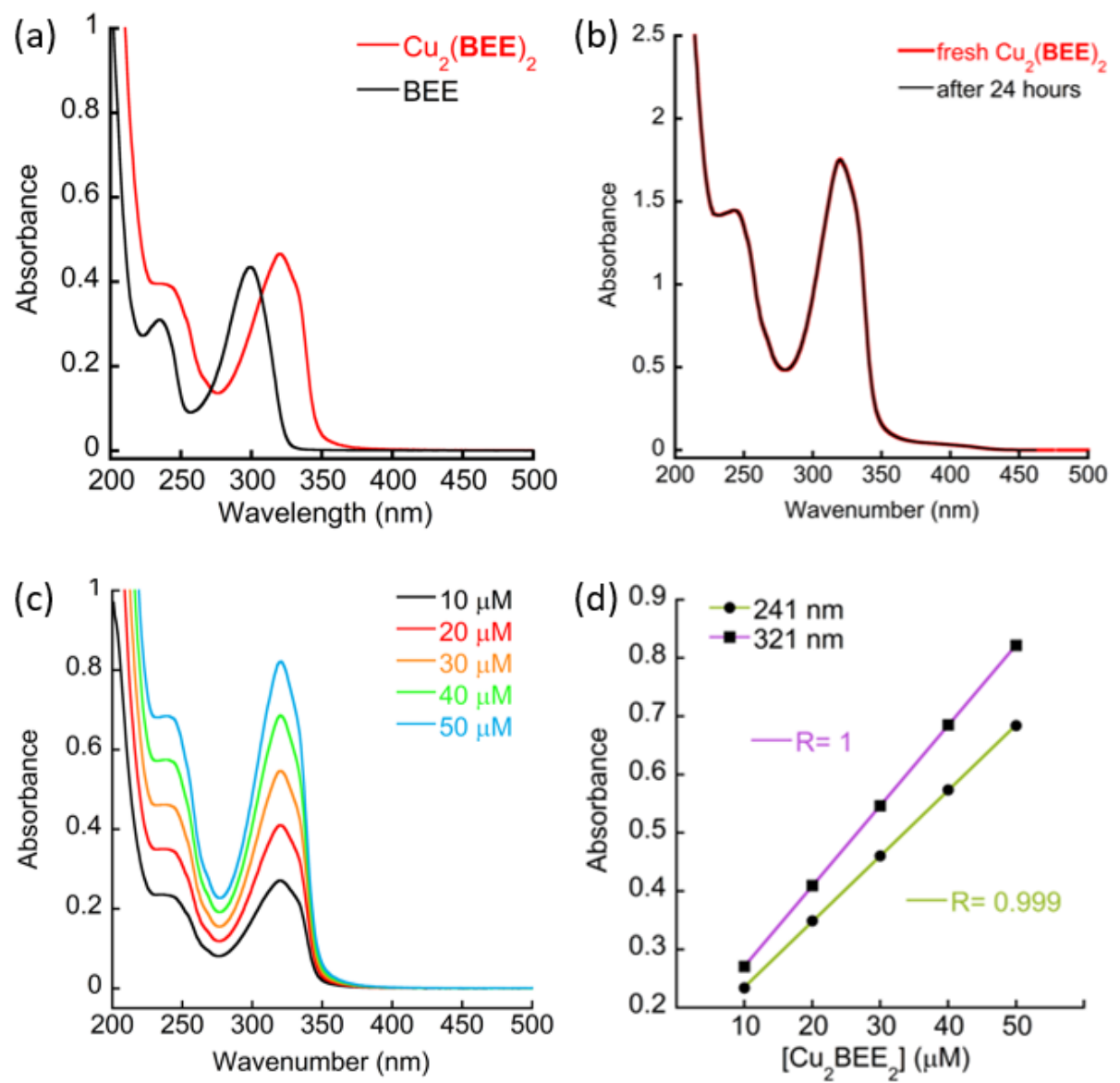

Figure S3. (a) UV-Vis of $\mathbf{B E E}$ and $\mathrm{Cu}_{2}(\mathbf{B E E})_{2}$ in $0.2 \mathrm{M}$ borate buffer at $\mathrm{pH} 9.35$; (b) UV-Vis of $\mathrm{Cu}_{2}(\mathbf{B E E})_{2}$ in borate buffer for 24 hours; (c) UV-Vis of different concentrations of $\mathrm{Cu}_{2}(\mathbf{B E E})_{2}$ in borate buffer; (d) linear plots of the absorbance peak at $241 \mathrm{~nm}$ and $321 \mathrm{~nm}$ from the figure (c).
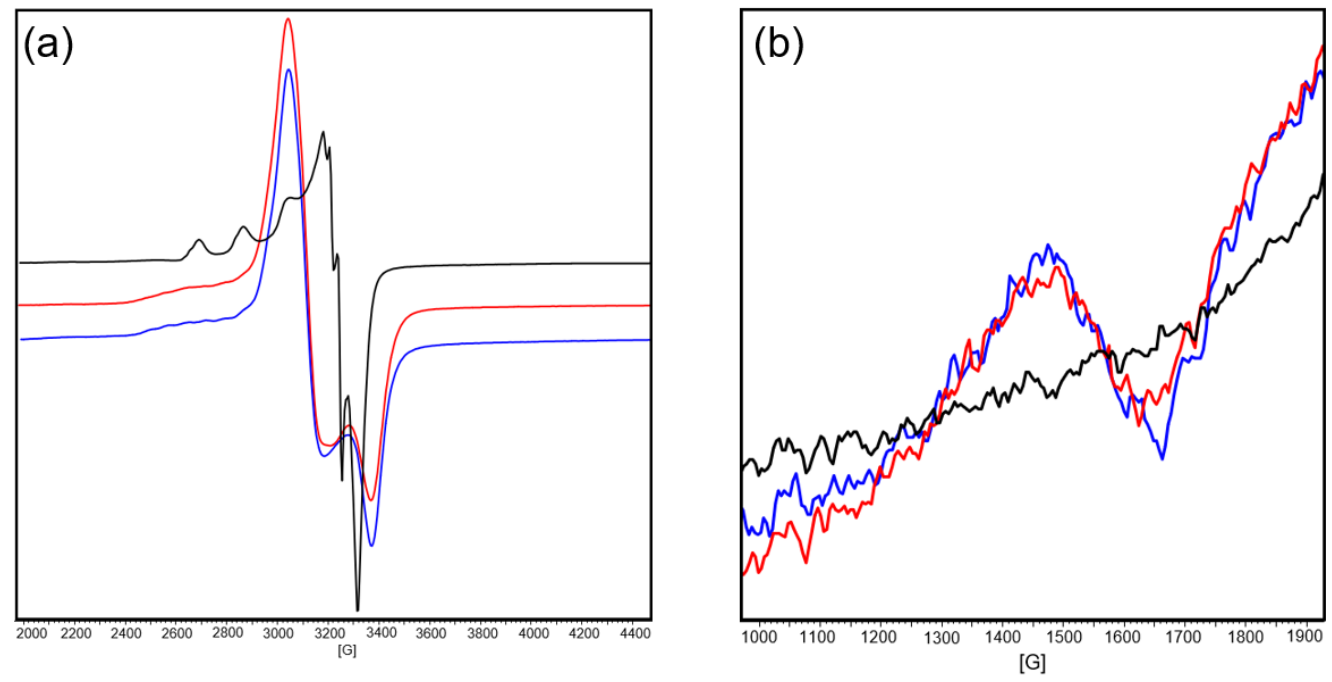

Figure S4. (a) EPR spectra of $\mathrm{Cu}_{2}(\mathbf{B E E})_{2}$ in $0.2 \mathrm{M}$ borate buffer at $\mathrm{pH} 7.50$ (red), 9.35 (blue), and 11.68 (black) from 2000 to $4500 \mathrm{G}\left(\Delta \mathrm{M}_{\mathrm{S}}= \pm 1\right)$; (b) the corresponding signals at half-field region $\left(\Delta \mathrm{M}_{\mathrm{S}}= \pm 2\right)$ at 6 -fold scale; all the experiments were done at $200 \mathrm{~K}$. 

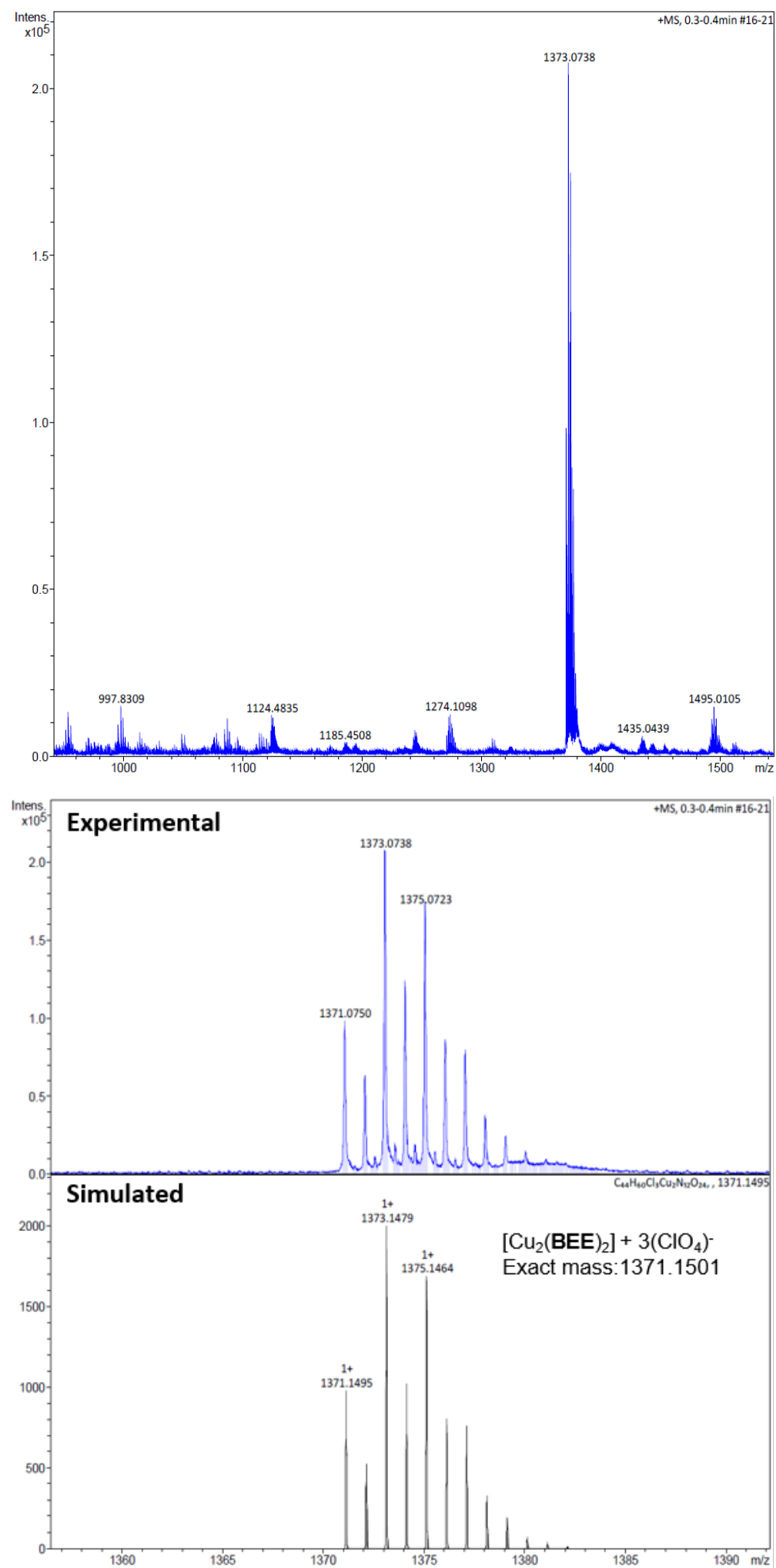


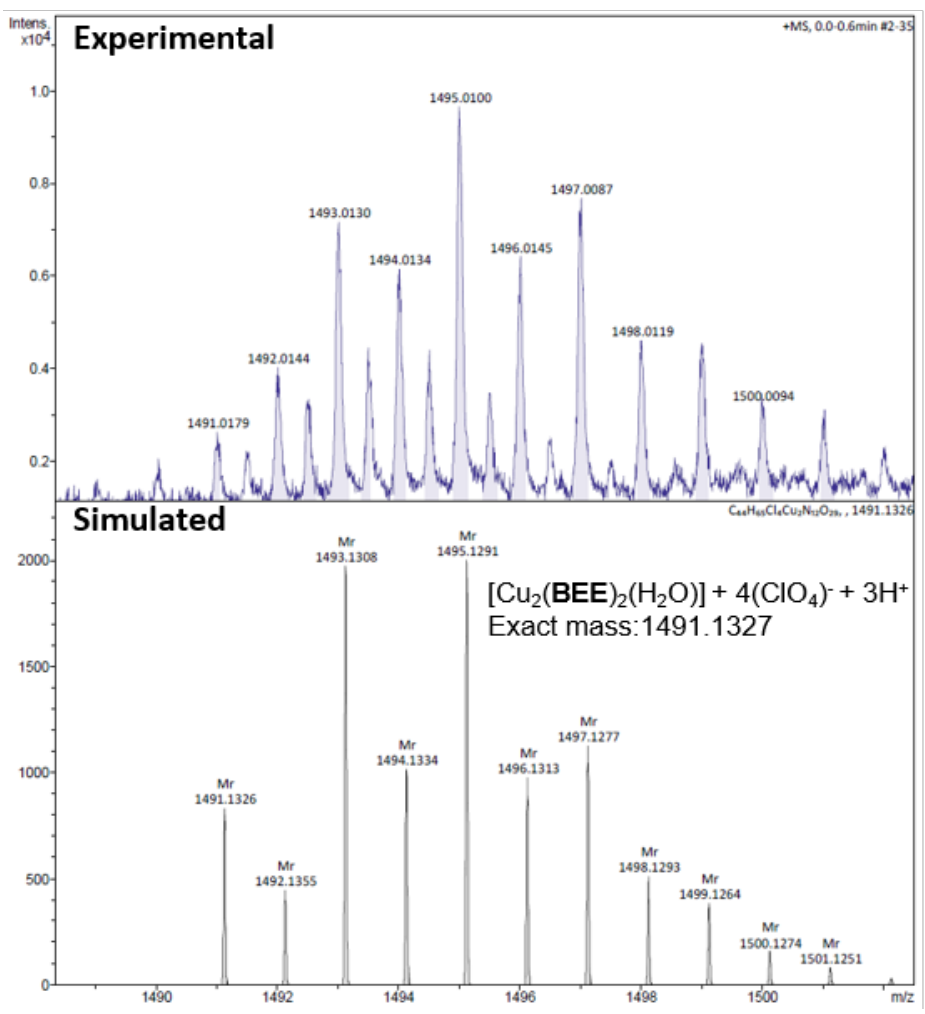

Figure S5. Top: ESI-MS of $\mathrm{Cu}_{2}(\mathbf{B E E})_{2}$; middle: experimental and simulated mass of $\left[\mathrm{Cu}_{2}(\mathbf{B E E})_{2}\right]+3 \mathrm{ClO}_{4}^{--}$; bottom: experimental and simulated mass of $\left[\mathrm{Cu}_{2}(\mathbf{B E E})_{2}\left(\mathrm{H}_{2} \mathrm{O}\right)\right]+3 \mathrm{H}^{+}$ $+4 \mathrm{ClO}_{4}^{-}$.

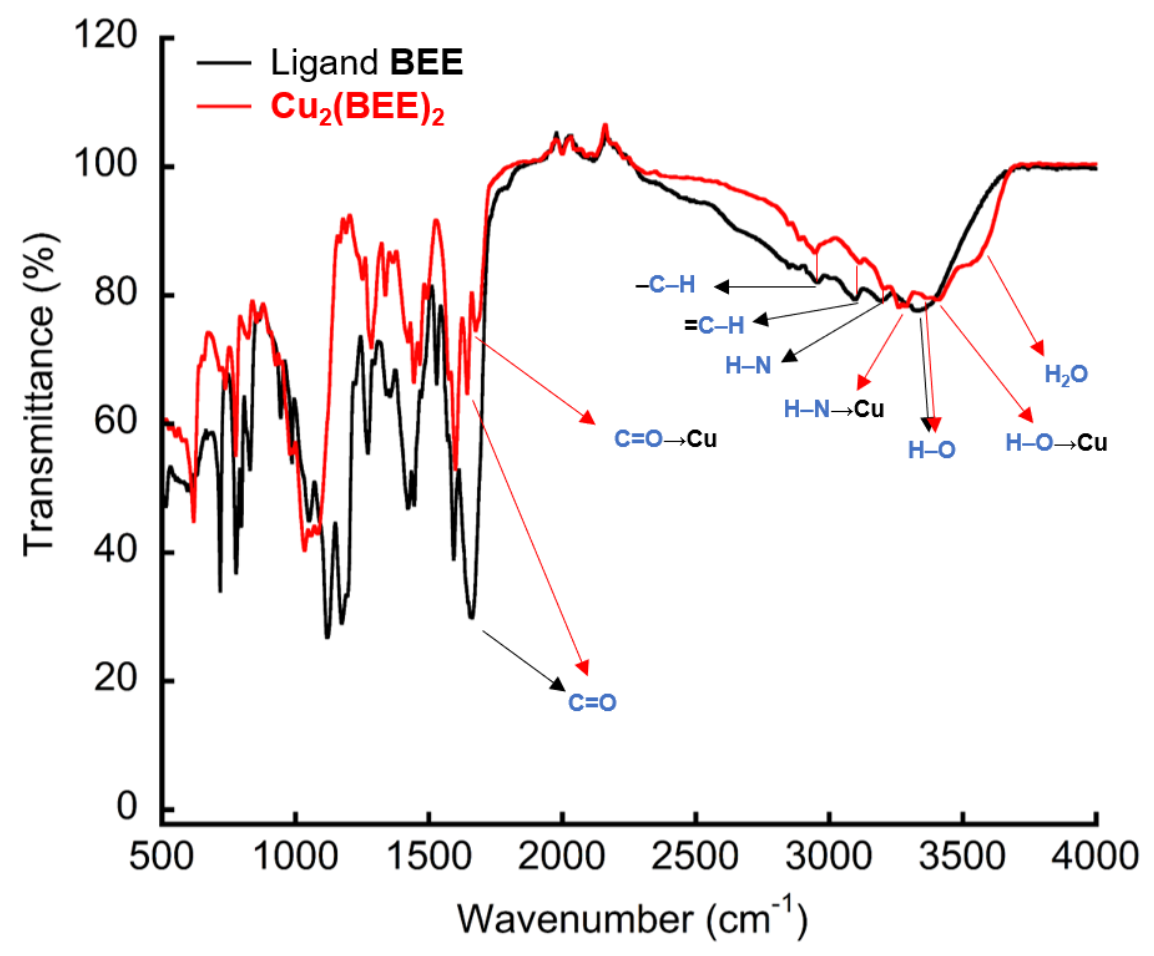

Figure S6. FTIR of BEE and its corosponding complex $\mathrm{Cu}_{2}(\mathbf{B E E})_{2}$; red arrows represent the signals of complex $\mathrm{Cu}_{2}(\mathbf{B E E})_{2}$, black arrows represent the signals of peptoid BEE, bond stretching contributed to corresponding peaks are marked in blue in the text. 


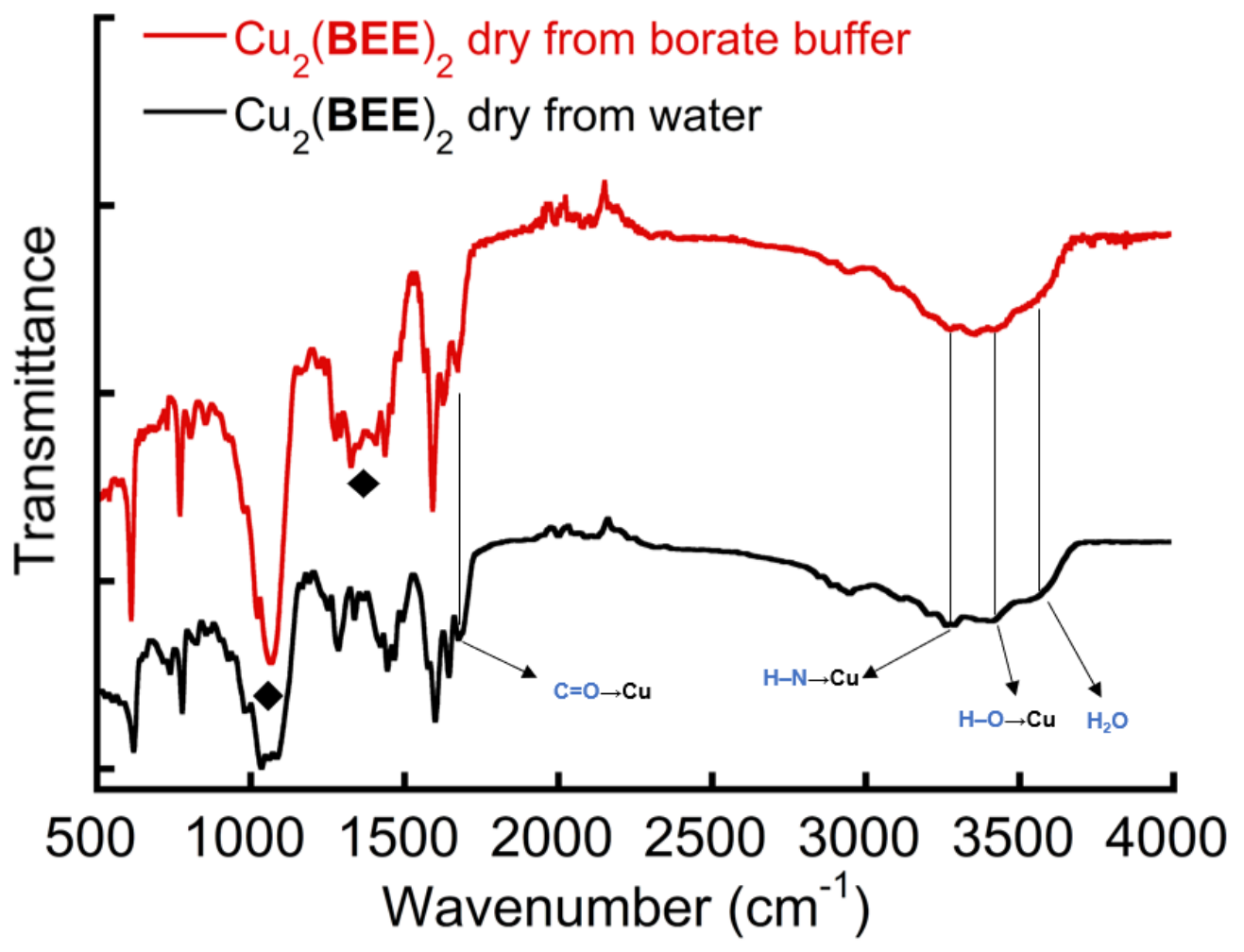

Figure S7. Powder FTIR of BEE and its corrosponding complex $\mathrm{Cu}_{2}(\mathbf{B E E})_{2}$ dried from different solutions. " " indicates stretching/bending from the borate species.

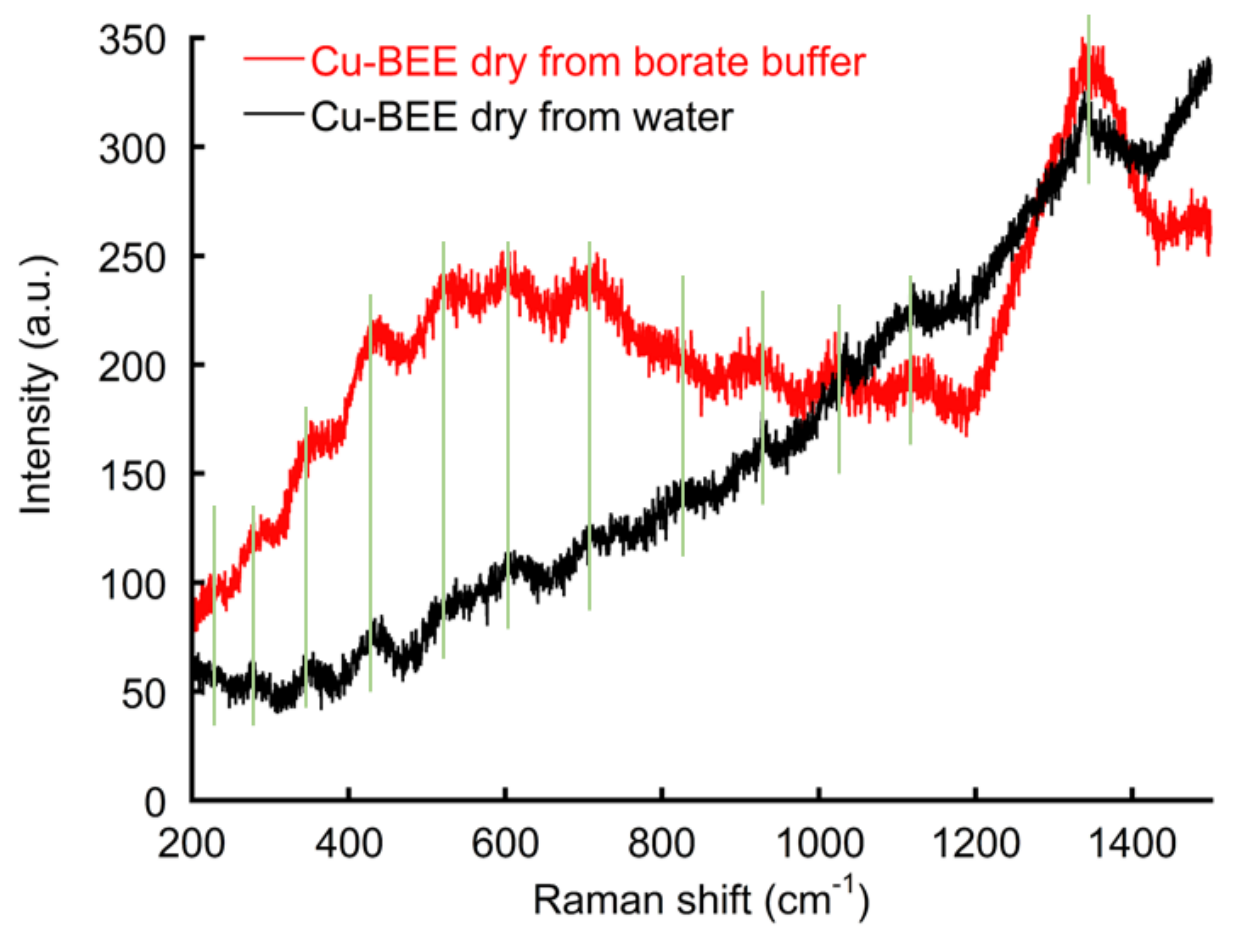

Figure S8. Raman spectroscopy of $\mathbf{B E E}$ and it corrosponding complex $\mathrm{Cu}_{2}(\mathbf{B E E})_{2}$ dried from different solutions. 

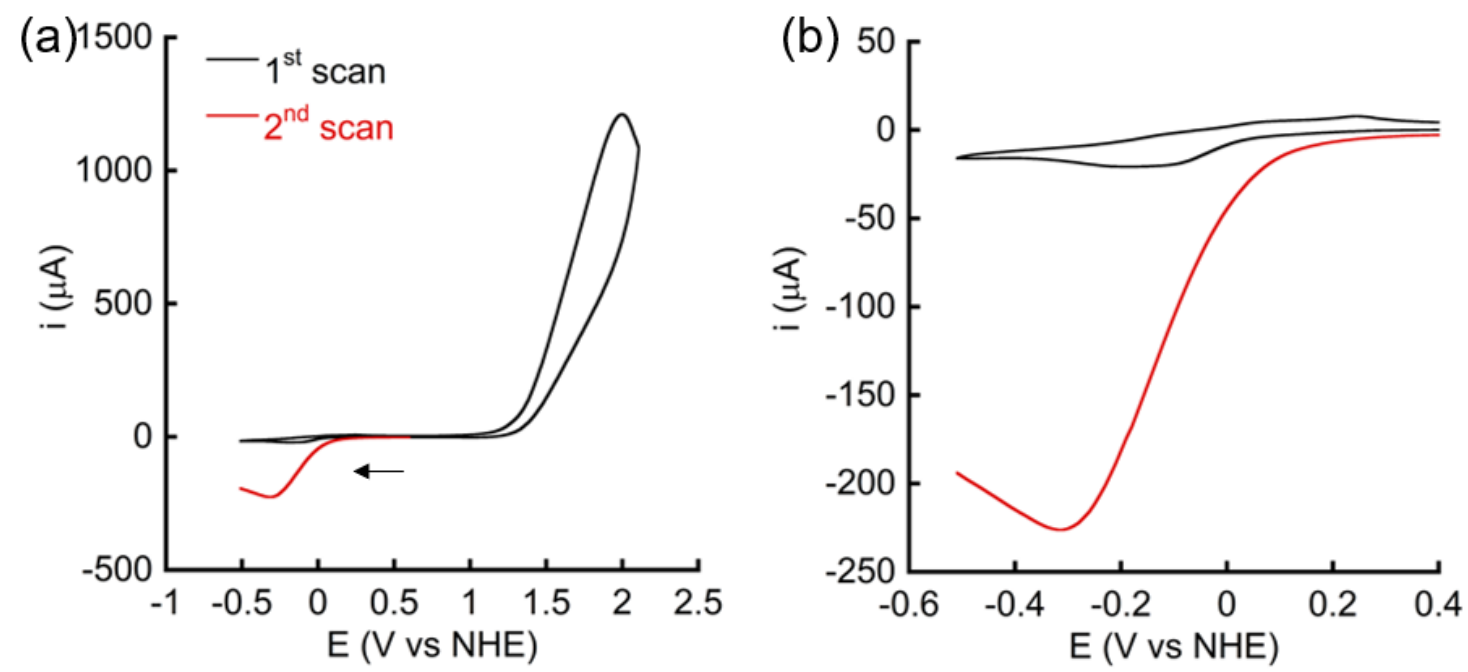

Figure S9. (a) Two continuous CV scans of $\mathrm{Cu}_{2}(\mathbf{B E E})_{2}$ in $0.2 \mathrm{M}$ borate buffer $\mathrm{pH} 9.35$ started from $+0.6 \mathrm{~V}$ to $-0.5 \mathrm{~V}$, then reversed to $+2.1 \mathrm{~V}$; (b) enlarged scale of the range of $-0.5 \mathrm{~V}$ to $+0.4 \mathrm{~V}$.

(a)

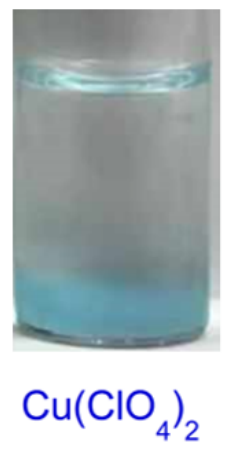

(b)

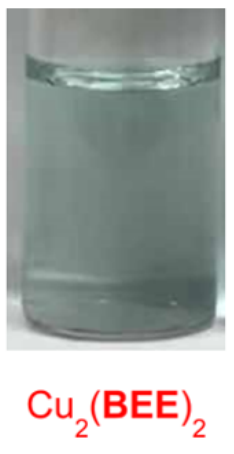

(c)

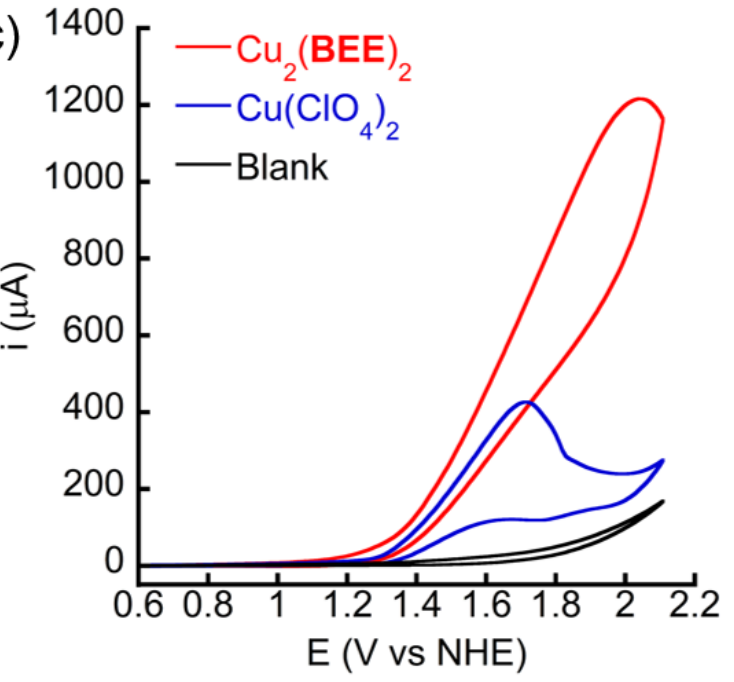

Figure $\mathrm{S} 10$. (a): $2.0 \mathrm{mM} \mathrm{Cu}\left(\mathrm{ClO}_{4}\right)_{2} \bullet 6 \mathrm{H}_{2} \mathrm{O}$ in $0.2 \mathrm{M}$ borate buffer at $\mathrm{pH}=9.35$; (b) $1.0 \mathrm{mM}$ $\mathrm{Cu}_{2}(\mathbf{B E E})_{2}$ in $0.2 \mathrm{M}$ borate buffer at $\mathrm{pH}=9.35$; (c) $\mathrm{CV}$ of $0.2 \mathrm{M}$ borate buffer solution at $\mathrm{pH}$ 9.35 with complex $\mathrm{Cu}_{2}(\mathbf{B E E})_{2}, \mathrm{Cu}\left(\mathrm{ClO}_{4}\right)_{2}$, and without any catalyst (blank), scan rate $=100$ $\mathrm{mV} / \mathrm{s}$. 


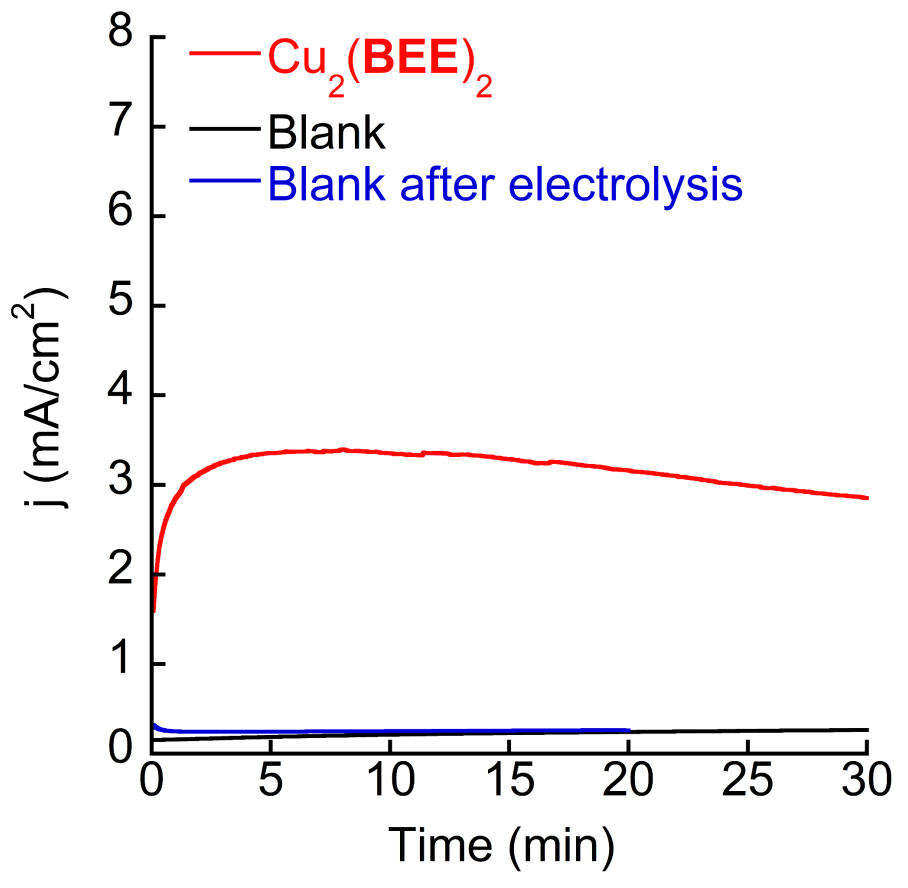

Figure S11. Current density of $\mathrm{Cu}_{2}(\mathbf{B E E})_{2}$ and blank solution from CPE experiment at applied potential $+1.35 \mathrm{~V}$ vs. NHE in $0.2 \mathrm{M}$ borate buffer at $\mathrm{pH} 9.35$; the working electrode was rinsed with fresh buffer solution after CPE experiment without polish and used for another 20-min CPE in blank solution.

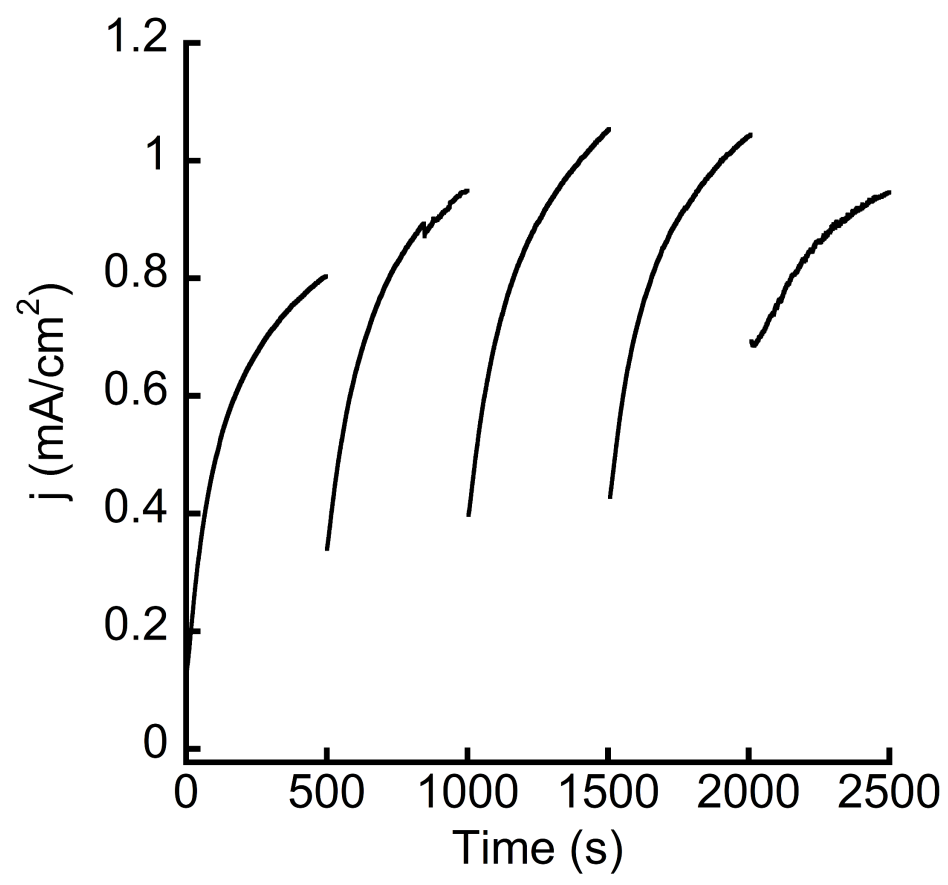

Figure S12. Five cycles of current density for initial 500 seconds of CPE experiments; all the cycles are done in the same solution with catalyst $\mathrm{Cu}_{2}(\mathbf{B E E})_{2}$ in $0.2 \mathrm{M}$ borate buffer at $\mathrm{pH}$ 9.35 with ITO as working electrode; there is 5-minute break between each cycle, except the last one that has only about 2 -minute break. 

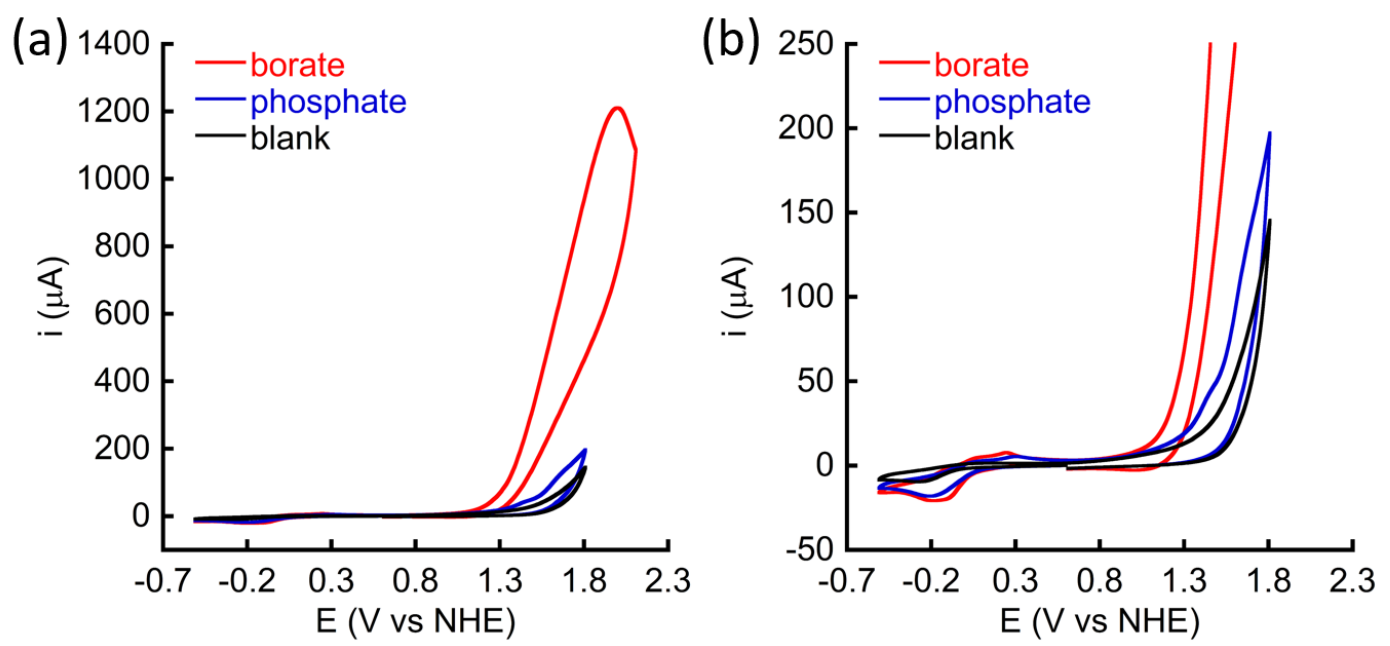

Figure S13. (a) CVs of $1 \mathrm{mM}$ of $\mathrm{Cu}_{2}(\mathbf{B E E})_{2}$ in $0.2 \mathrm{M}$ borate buffer or phosphate buffer at $\mathrm{pH}$ 9.35, and a blank scan in phosphate buffer without catalyst; (b) the enlarged scale of (a) for clarity.

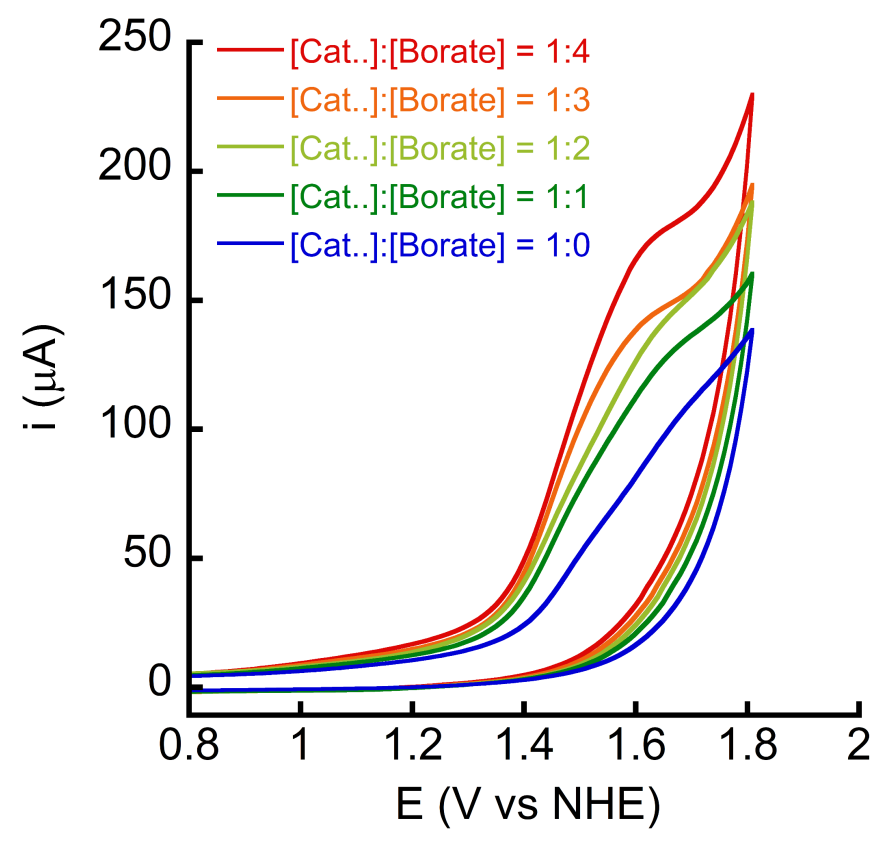

Figure S14. (a) CVs for a series of titrations: certain amounts of $0.2 \mathrm{M}$ borate buffer at $\mathrm{pH}$ 9.35 (based on the amount of catalyst) were added into a solution containing $0.5 \mathrm{mM}$ of $\mathrm{Cu}_{2}(\mathbf{B E E})_{2}$ in $0.2 \mathrm{M}$ phosphate buffer at $\mathrm{pH} 9.35$; noted that the volume of additional borate buffer is in $\mu \mathrm{L}$ scale, which has a negligible effect for the concentration change of catalyst, which is in $\mathrm{mL}$ scale. 

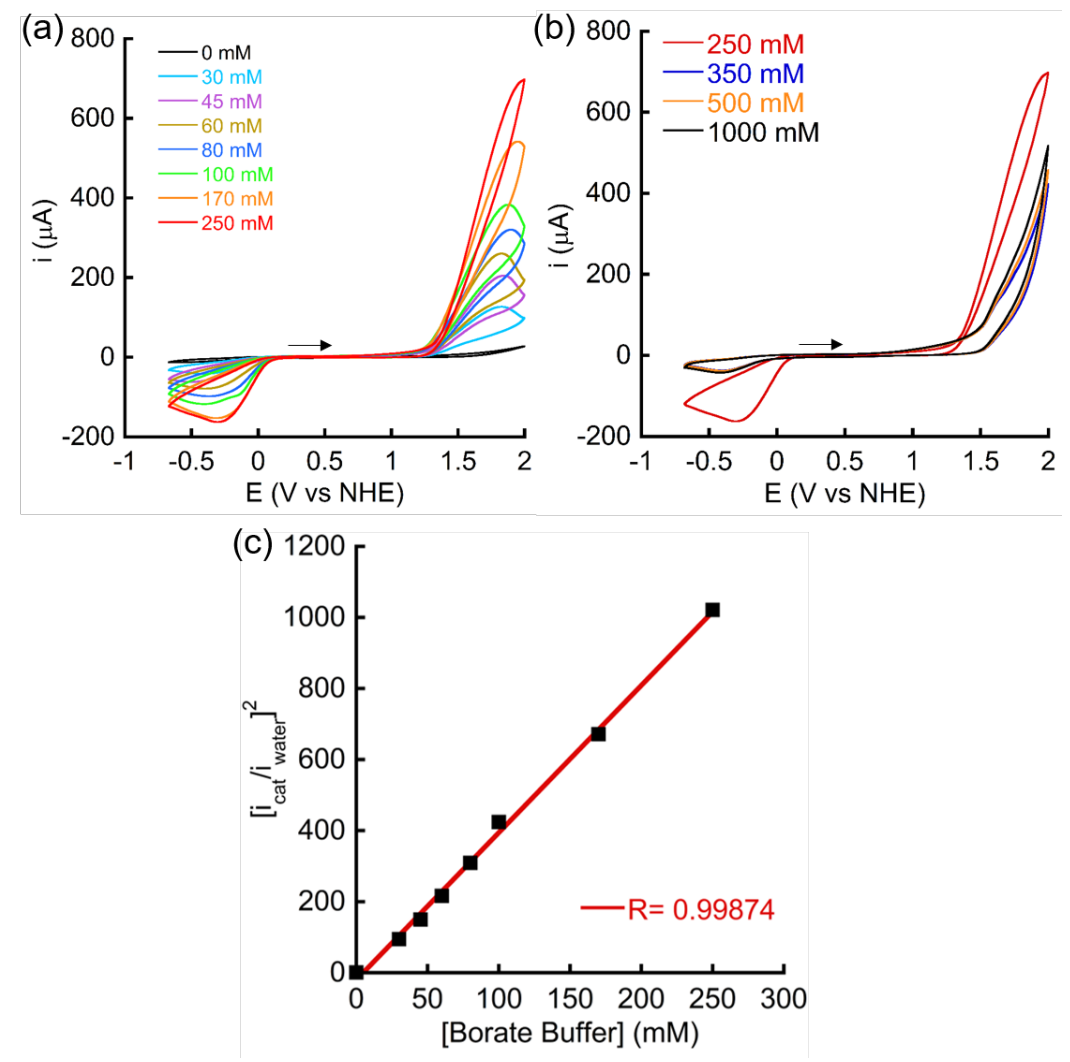

Figure S15. (a) and (b): CV scans of $0.5 \mathrm{mM} \mathrm{Cu}_{2}(\mathbf{B E E})_{2}$ in different concentrations of borate buffer at $\mathrm{pH}$ 9.35, the ion strength is maintained as $0.2 \mathrm{M}$ with $\mathrm{KNO}_{3}$; arrows represent the scan direction, the oxygen reduction intensities at $-0.3 \mathrm{~V}$ are consistent with the catalytic intensity, at high concentration of borate buffer, the oxygen amount decreases. (c) Plot of $\left(\mathrm{i}_{\text {cat }} / \mathrm{i}_{\text {water }}\right)^{2}$ vs. concentrations. 

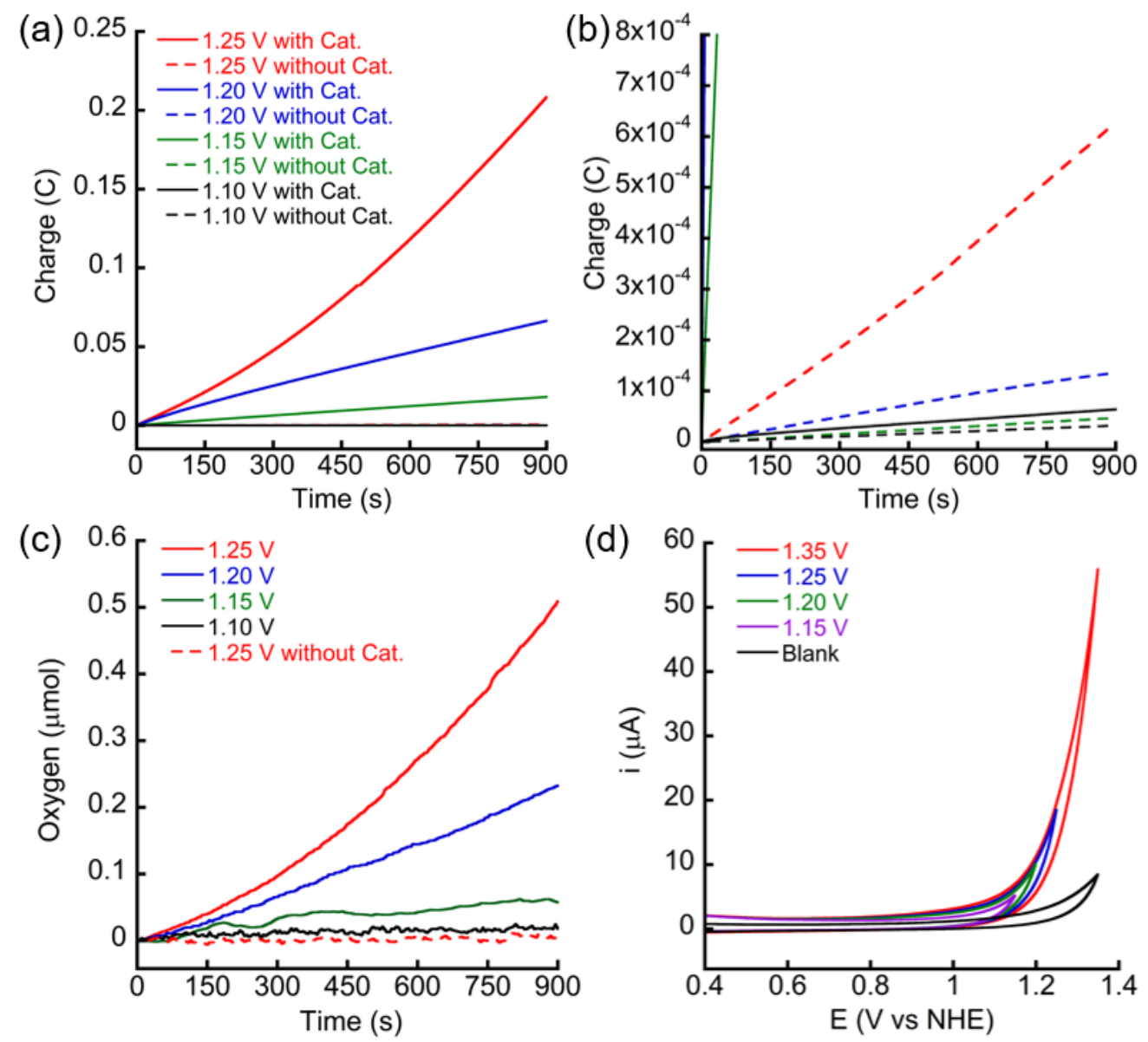

Figure S16. (a) Accumulated charges of CPE experiments at different applied potentials; (b) enlarged scale of figure (a) for clarity; (c) obtained oxygen from corresponding CPE experiments (here we only show the amount of oxygen at $+1.25 \mathrm{~V}$ without catalyst $\mathrm{Cu}_{2}(\mathbf{B E E})_{2}$ instead of showing all others without catalyst is because they are the same that no oxygen generated); (d) $\mathrm{CV}$ scans of $\mathrm{Cu}_{2}(\mathbf{B E E})_{2}$ in different range of potentials.
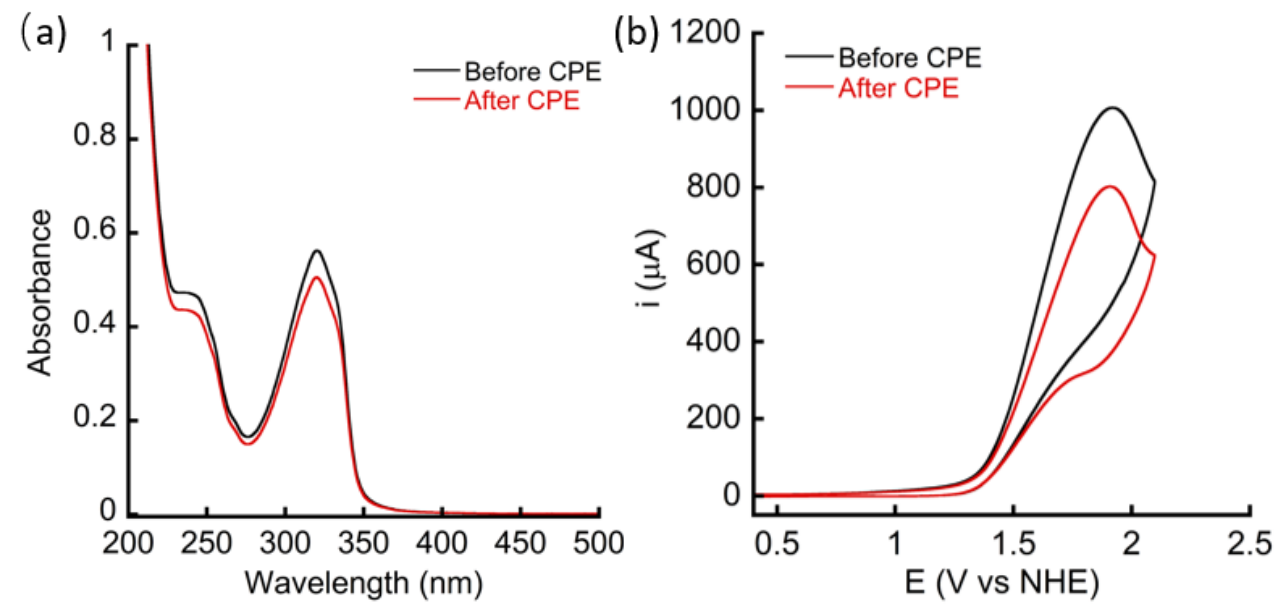

Figure S17. (a) UV-Vis and (b) CV scans of before and after CPE experiment of $0.5 \mathrm{mM}$ $\mathrm{Cu}_{2}(\mathbf{B E E})_{2}$ in $0.2 \mathrm{M}$ borate buffer solution at $\mathrm{pH} 9.35$. 
(a)

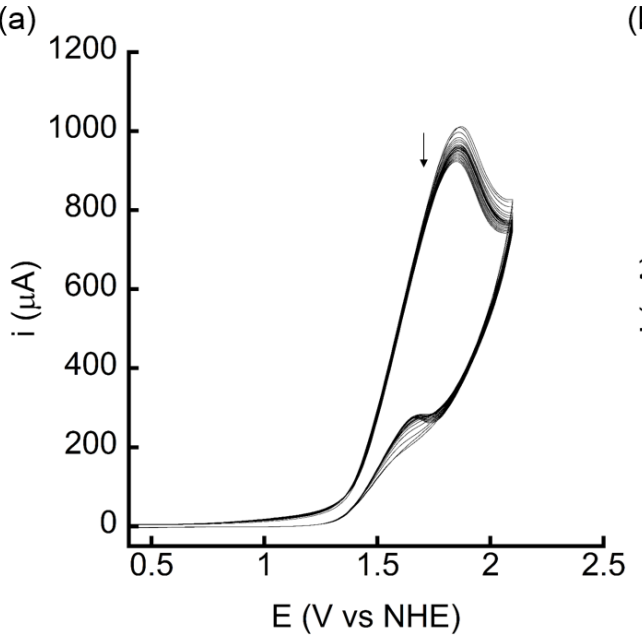

(b)

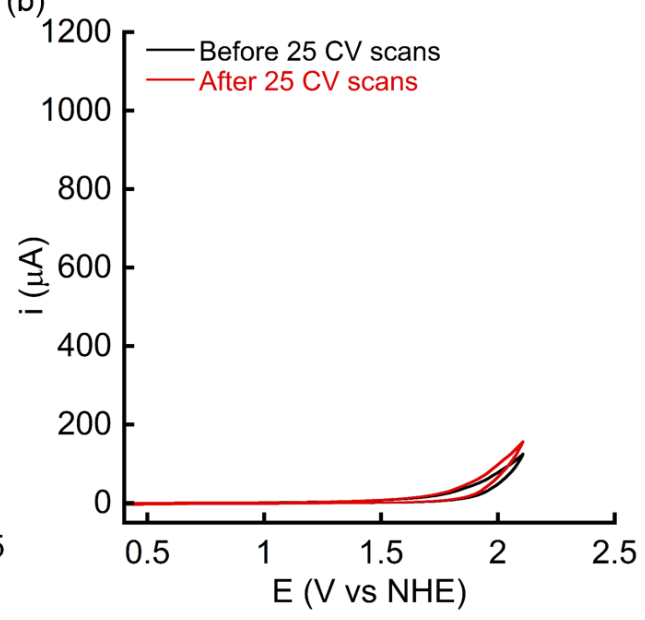

Figure S18. (a) 25 continuous $\mathrm{CV}$ scans of solution containing $0.5 \mathrm{mM}$ of complex $\mathrm{Cu}_{2}(\mathbf{B E E})_{2}$ in $0.2 \mathrm{M}$ borate buffer at $\mathrm{pH} 9.35$ on a glassy carbon $\left(\mathrm{S}=0.07 \mathrm{~cm}^{2}\right)$ as working electrode, scan rate $\mathrm{v}=100 \mathrm{mV} \mathrm{s}^{-1}, \mathrm{~T}=298 \mathrm{~K}$. (b) CVs for working electrode before and after 25 continuous CV scans, scan rate $\mathrm{v}=100 \mathrm{mV} \mathrm{s}^{-1}, \mathrm{~T}=298 \mathrm{~K}$.

(a)

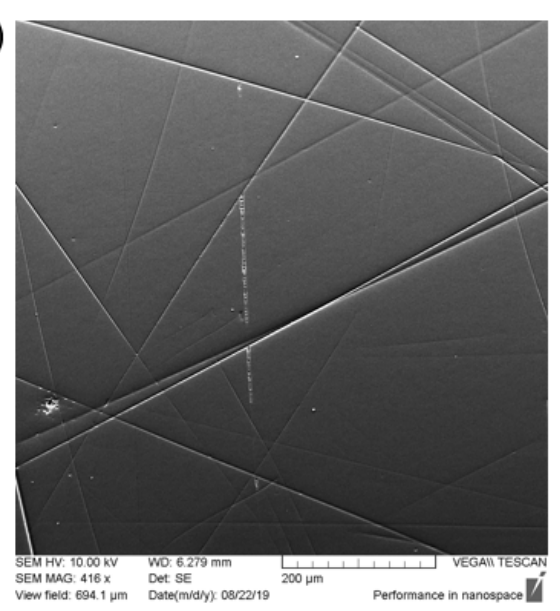

(c)

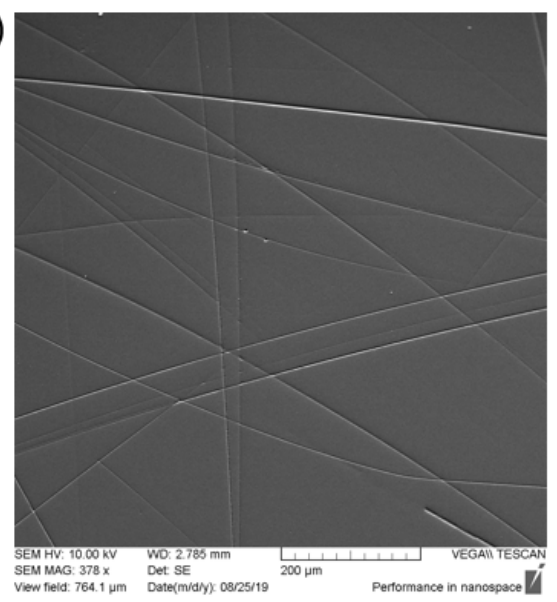

(b)

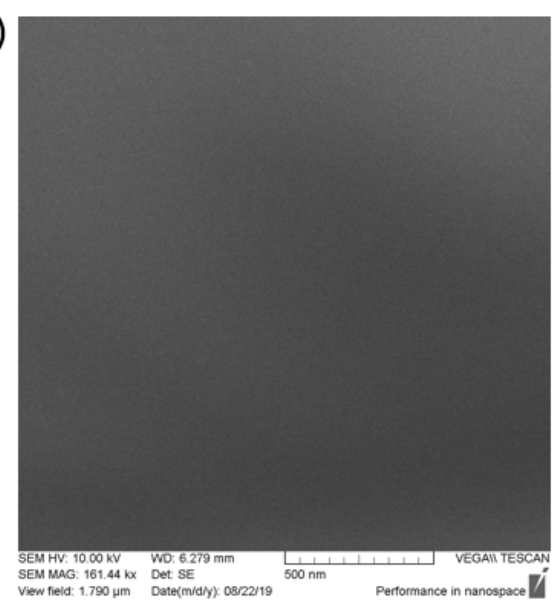

(d)

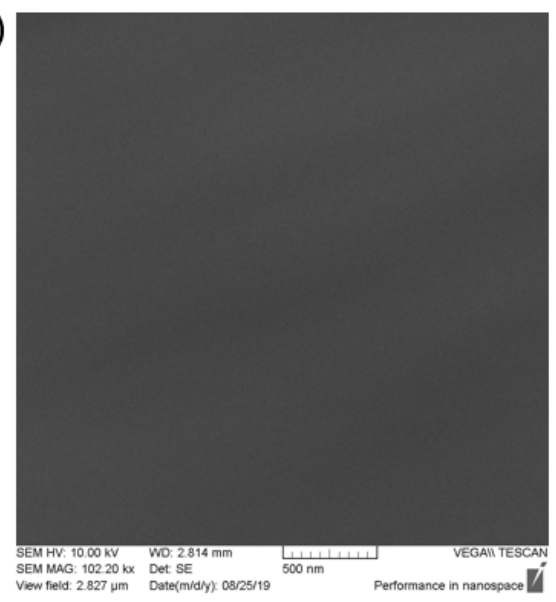

Figure S19. SEM images of glassy carbon electrode before (a \& b) and after (c \& d) successive $25 \mathrm{CV}$ scans measured on a different scale. 


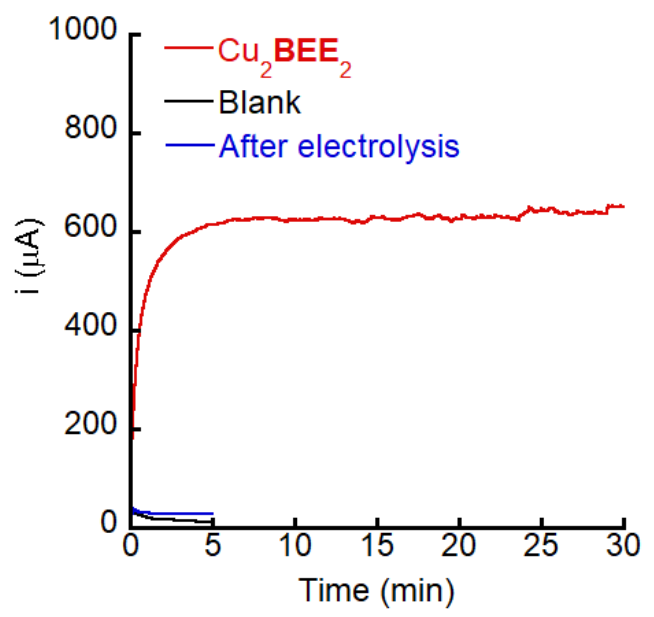

Figure S20. Current responses of $\mathrm{CPE}$ at $+1.35 \mathrm{~V}$ containing $\sim 0.3 \mathrm{mM} \mathrm{Cu}_{2} \mathbf{B E E}_{2}$ in $0.2 \mathrm{M}$ borate buffer solution at $\mathrm{pH} 9.35$ using ITO as working electrode; the current response of ITO before (blank) and after electrolysis in blank buffer solution are shown for the beginning of 5 mins.

(a)

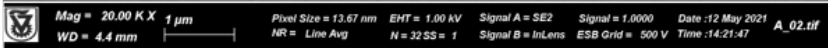

(b) 

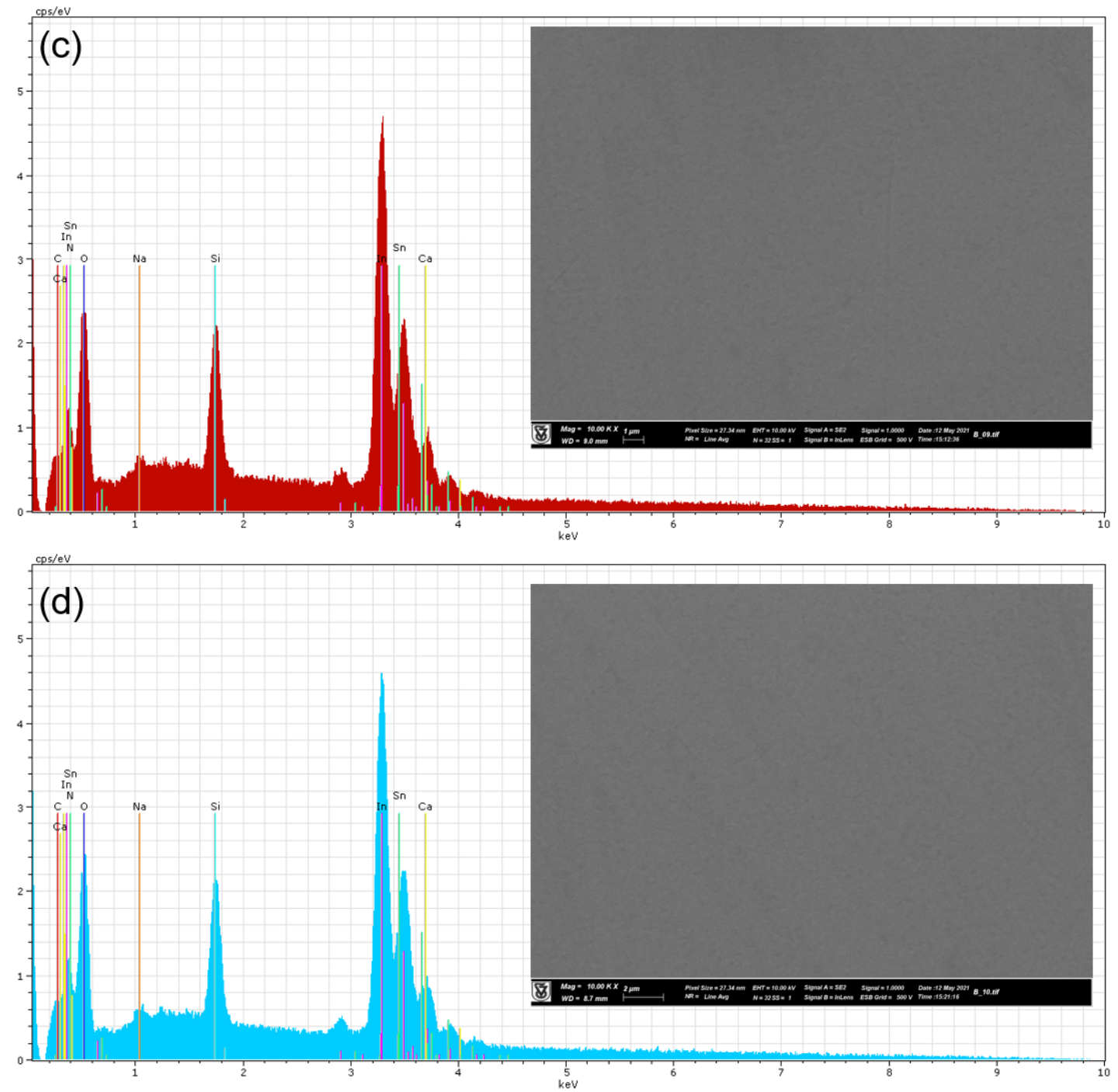

Figure S21. (a) HR-SEM image of fresh ITO electrode; (b) HR-SEM image of ITO electrode after 30-min CPE experiment; (c) \& (d) EDS analysis of ITO electrode after electrolysis in different location; no $\mathrm{Cu}$ element was detected at $\sim 8 \mathrm{keV}\left(\mathrm{K}_{\alpha}\right)$ and $\sim 9 \mathrm{keV}\left(\mathrm{K}_{\beta}\right)$. For confirmation of sample composition, an acceleration voltage of $10 \mathrm{kV}$ (from $1 \mathrm{kV}$ ) was used. This higher acceleration voltage was needed for sufficient X-ray emission from the specimens. 


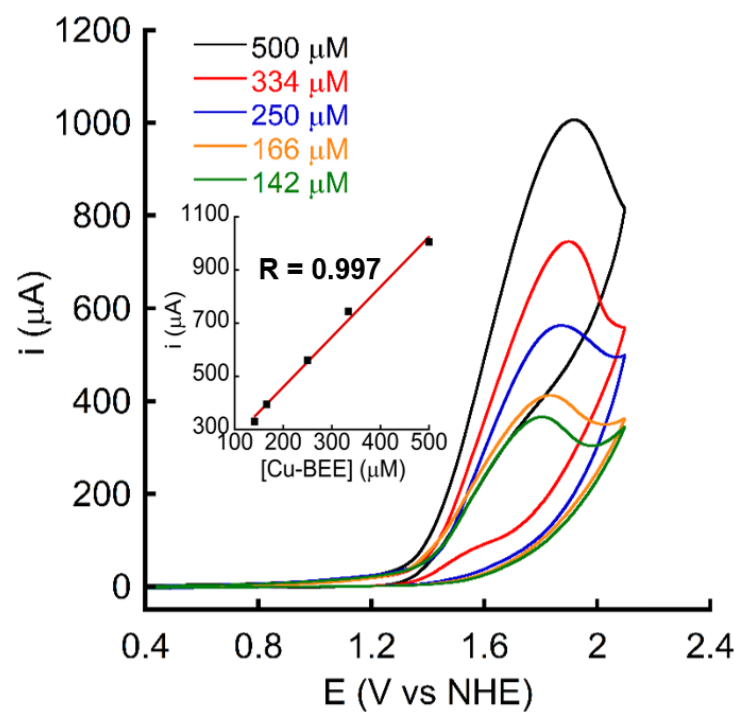

Figure S22. CVs of different concentrations of $\mathrm{Cu}_{2}(\mathbf{B E E})_{2}$ in $0.2 \mathrm{M}$ borate buffer at $\mathrm{pH} 9.35$ at scan rate $100 \mathrm{mV} / \mathrm{s}$; inset shows the linear regression of $i_{\text {cat }}$ versus concentrations.
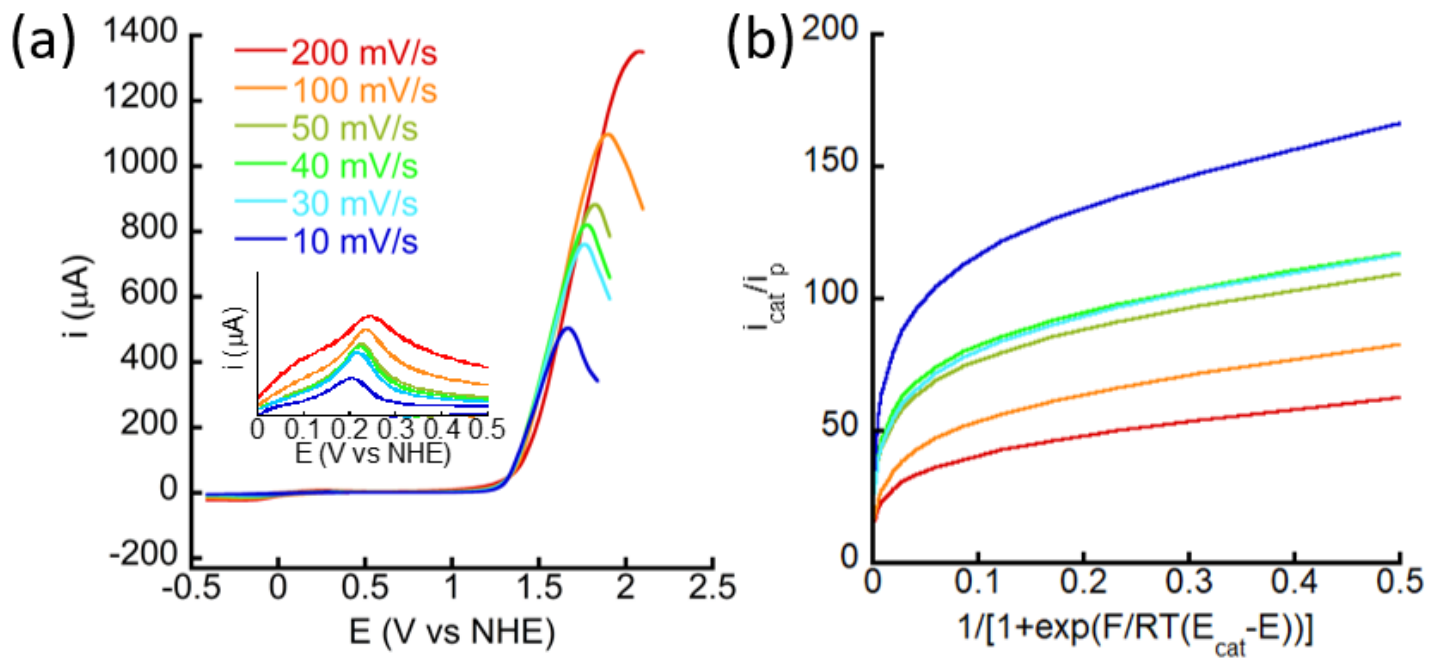

Figure S23. (a) CVs of $\mathrm{Cu}_{2}(\mathbf{B E E})_{2}$ at different scan rates in $0.2 \mathrm{M}$ borate buffer at $\mathrm{pH} 9.35$, using glassy carbon working electrode; (b) FOWA plotting icat/ip v. $1 /\left(1+\exp \left[\left(\mathrm{E}_{\text {cat }}-\mathrm{E}\right) \mathrm{F} / \mathrm{RT}\right]\right)$ at each scan rate. The calculation of $\mathrm{k}_{\mathrm{obs}}$ was followed eq.S3, herein we regarded the peak current of $\mathrm{Cu}_{2}{ }^{\mathrm{II}} / \mathrm{Cu}^{\mathrm{II}} \mathrm{Cu}^{\mathrm{I}}$ as the non-catalytic peak (insert) before catalytic event, ip. ${ }^{4}$ The averaged $\mathrm{k}_{\text {obs }}$ value $5503 \mathrm{~s}^{-1}$ was calculated from the mean of $6015,5414,4695,5658,6262$, $4977 \mathrm{~s}^{-1}$ from scan rates $200,100,50,40,30,10 \mathrm{mV} / \mathrm{s}$, respectively. 

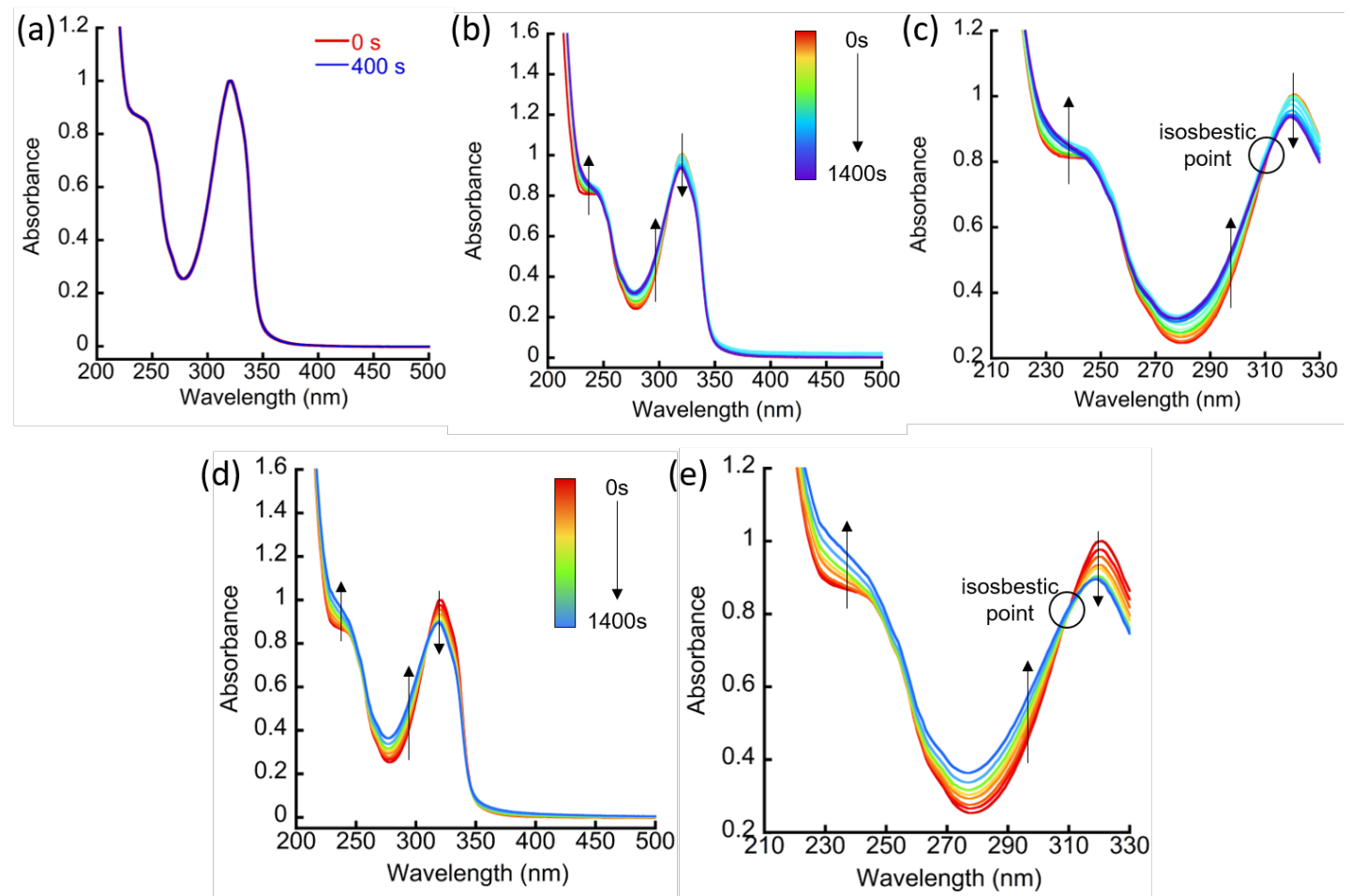

Figure S24. Spectroelectrochemistry experiments: (a) UV-Vis spectra during CPE at $+1.10 \mathrm{~V}$ vs. NHE for 400 seconds; (b) UV-Vis spectra during CPE at $+1.35 \mathrm{~V}$ vs. NHE for 1400 seconds; (c) enlarged scale of (b); (d) UV-Vis spectra during CPE at +1.55 V vs. NHE for 1400 seconds; (e) enlarged scale of (d). All the experiments were done in $0.2 \mathrm{M}$ borate buffer containing $0.5 \mathrm{mM}$ of $\mathrm{Cu}_{2}(\mathbf{B E E})_{2} \mathrm{pH} 9.35$, with $\mathrm{Pt}$ net as working electrode, $\mathrm{Ag} / \mathrm{AgCl}$ as reference electrode, and $\mathrm{Pt}$ wire as counter electrode.
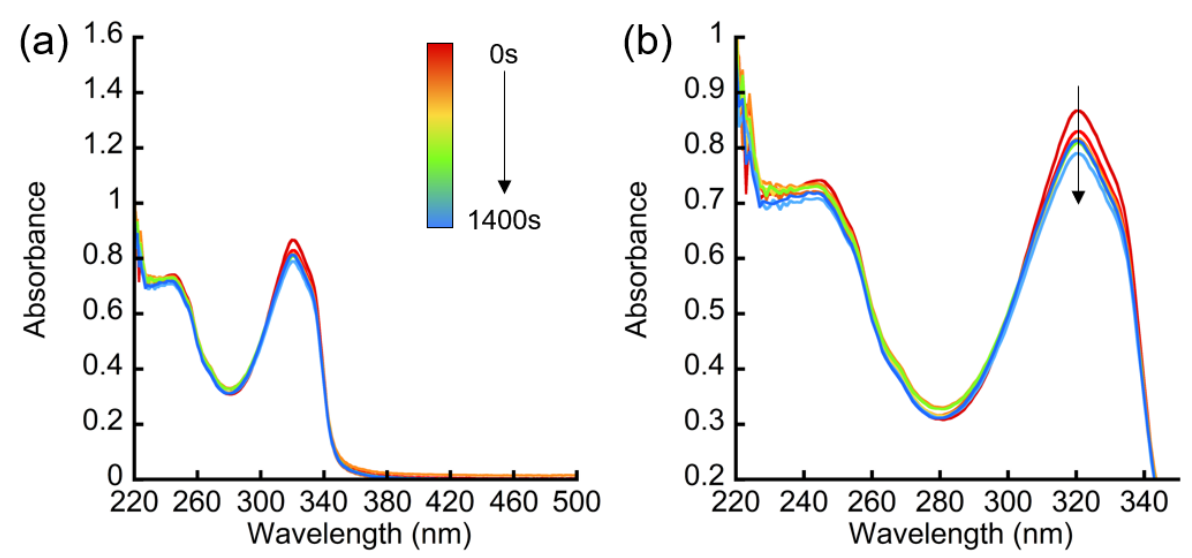

Figure S25. Spectroelectrochemistry experiments: (a) UV-Vis spectra during CPE at $+1.60 \mathrm{~V}$ vs. NHE for 1400 seconds in $0.2 \mathrm{M}$ phosphate buffer containing $\sim 0.5 \mathrm{mM}$ of $\mathrm{Cu}_{2}(\mathbf{B E E})_{2} \mathrm{pH}$ 9.35; (b) enlarged scale of (a). 


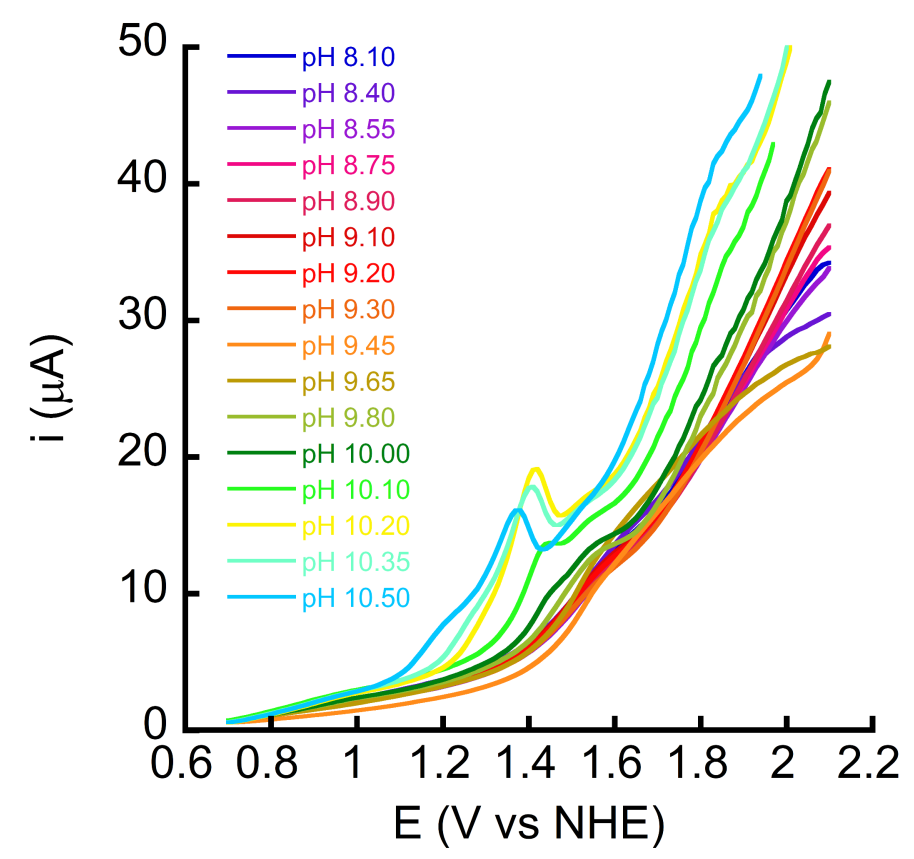

Figure $\mathrm{S} 26$. DPVs of $\mathrm{Cu}_{2}(\mathbf{B E E})_{2}$ in $0.2 \mathrm{M}$ borate buffer at different $\mathrm{pH}$ units ranged from 8.10 to 10.50 .

(a)

$$
\begin{aligned}
& {\left[\mathrm{Cu}_{2} \mathrm{II}_{2}(\mathbf{B E E})_{2}\left(\mathrm{H}_{2} \mathrm{O}\right)\right]^{4+}+\left[\mathrm{B}(\mathrm{OH})_{4}\right] \rightarrow} \\
& \left\{\mathrm{Cu}_{2} \mathrm{III}_{2}(\mathbf{B E E})_{2}(\mathrm{OH})\left[\mathrm{B}(\mathrm{O})(\mathrm{OH})_{3}\right]\right\}^{3+}+2 \mathrm{H}^{+}+2 \mathrm{e}^{-}
\end{aligned}
$$

(b)

$$
\begin{aligned}
E_{o x} & =E_{o x}^{o}-\frac{R T}{n F} \ln \left(\frac{\left\{\left[B(O H)_{4}\right]^{-}\right\}^{m}}{\left[H^{+}\right]^{2}}\right) \\
& =E_{o x}^{o}-m \times 0.013 \ln \left(\left\{\left[B(O H)_{4}\right]^{-}\right\}\right)-0.059 \times p H
\end{aligned}
$$

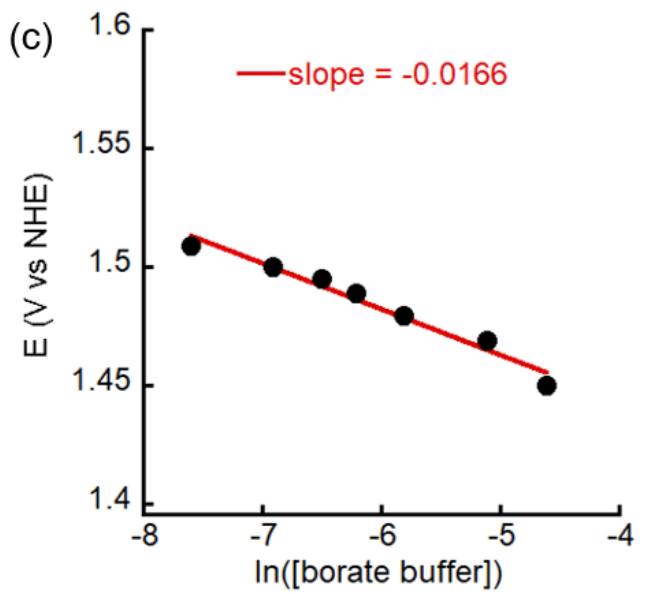

Figure S27. (a) Proposed stoichiometries of step 1 in mechanism cycle; (b) Nernst equation describing the relationship between $\mathrm{E}$ and concentrations of borate buffer as well as proton; $\mathrm{n}$ $=2$ (two-electron process); m equals to the stoichiometry of $\left[\mathrm{B}(\mathrm{OH})_{4}\right]^{-}$; (c) plot of $\mathrm{E}$ vs. the natural logarithm of $\left[\mathrm{B}(\mathrm{OH})_{4}\right]^{-}$concentration for catalyst $\mathrm{Cu}_{2}(\mathbf{B E E})_{2}$. The slope of $\mathrm{E}$ vs. $\ln ([$ Borate buffer] $)$ was calculated to be -0.166 , which is close to -0.013 ; that means the value $\mathrm{m}$ in (b) equals to 1 . 


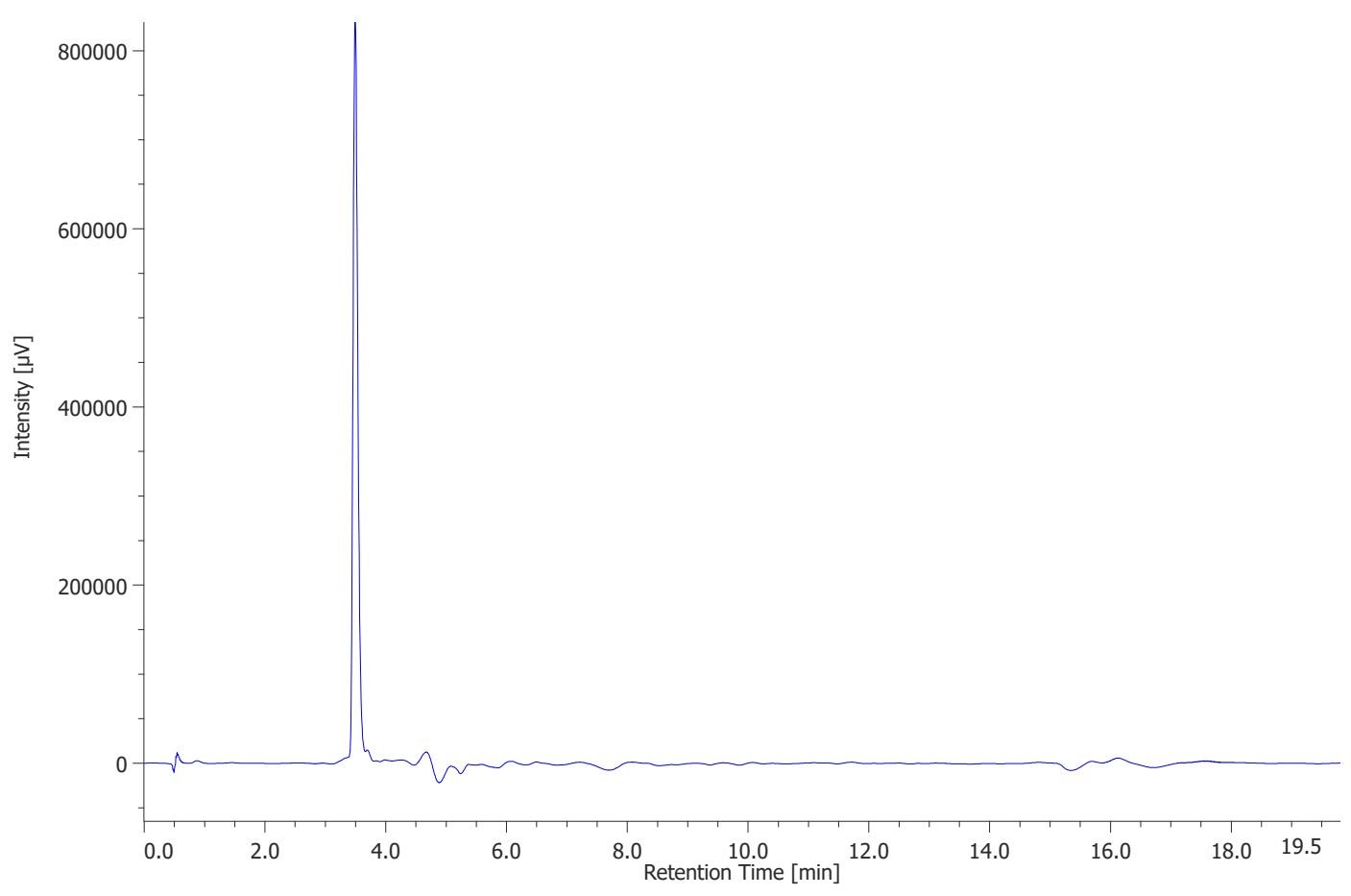

Figure S28. Analytical HPLC of purified peptoid BE in water/acetonitrile with 0.1\% TFA.

Intensity Spectrum RT $0.42\{1$ scans $\}$
gr_18_8_mim_2.datx 2020.01.06 17:08: 25

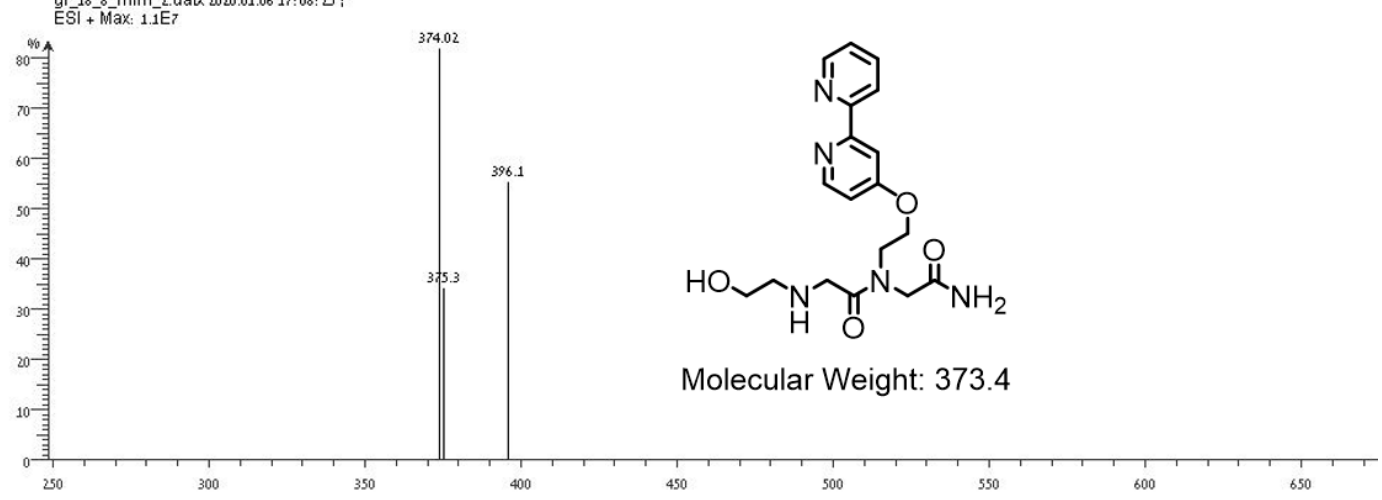

Figure S29. ESI-MS of purified peptoid $\mathbf{B E}$ in water, $\mathrm{m} / \mathrm{z}\left(\mathbf{B E}+\mathrm{H}^{+}\right)=374.02, \mathrm{~m} / \mathrm{z}\left(\mathbf{B E}+\mathrm{Na}^{+}\right)$ $=396.1$. 


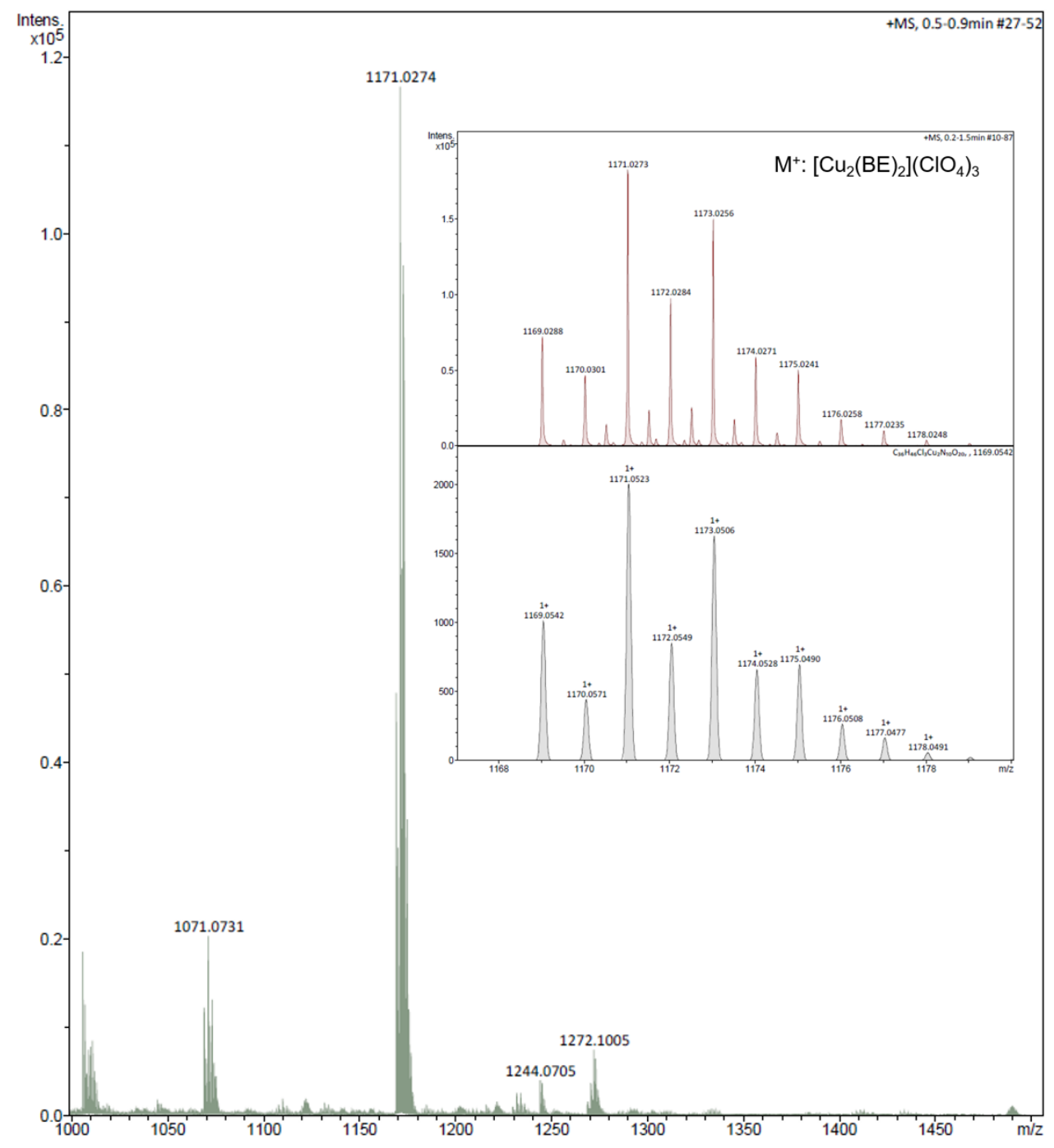

Figure S30. ESI-MS of $\mathrm{Cu}_{2}(\mathbf{B E})_{2} ; \mathrm{m} / \mathrm{z}\left[\left(\mathrm{Cu}_{2}(\mathbf{B E})_{2}\right)\left(\mathrm{ClO}_{4}\right)_{3}=1171\right.$; insert is the simulated result.
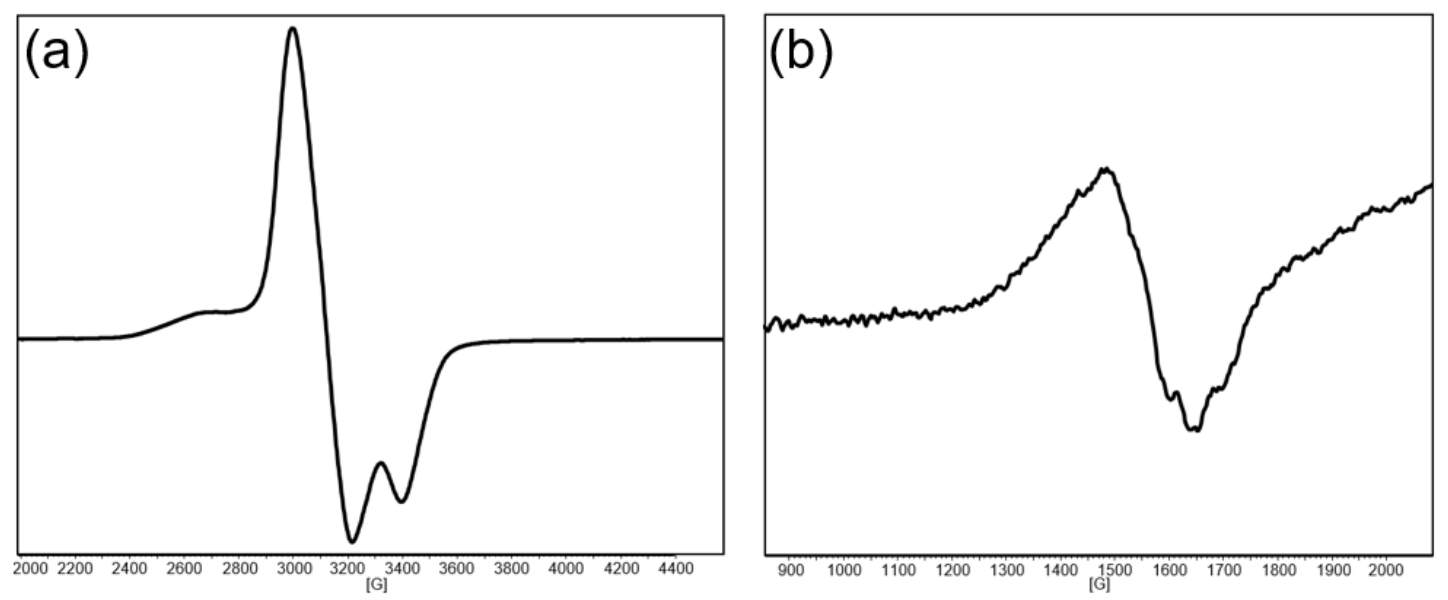

Figure S31. EPR of (a) $\mathrm{Cu}_{2}(\mathbf{B E})_{2}$ powder and (b) a solution of $0.5 \mathrm{mM} \mathrm{Cu}_{2}(\mathbf{B E})_{2}$ in $0.2 \mathrm{M}$ borate buffer at $\mathrm{pH} 9.35$; the solid phase measurement was done at room temperature ( $298 \mathrm{~K})$ and the solution phase measurement was done at $200 \mathrm{~K}$. 


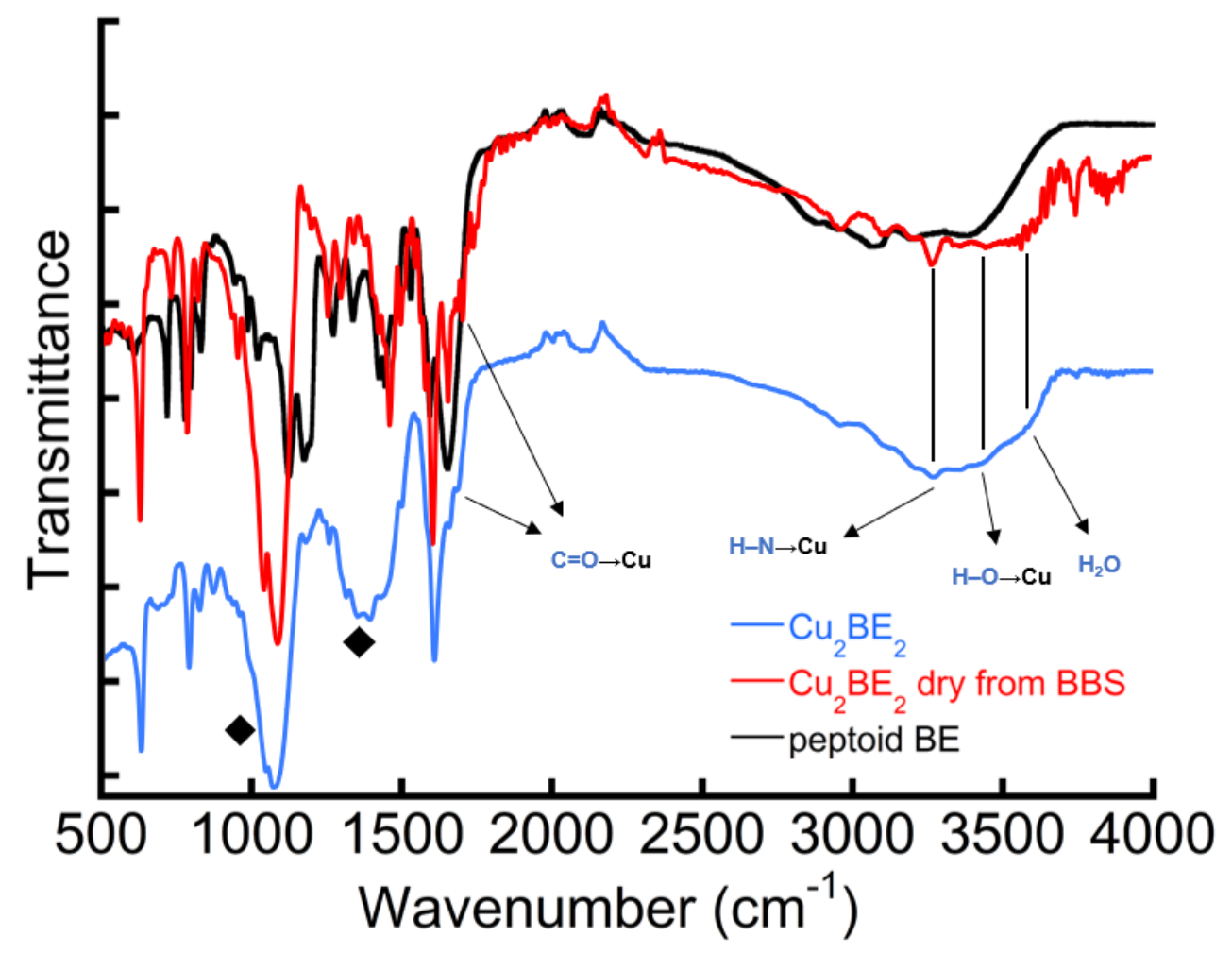

Figure S32. Powder FTIR of peptoid $\mathbf{B E}$ and complex $\mathrm{Cu}_{2}(\mathbf{B E})_{2}$ from crystal and dried from borate buffer (" $\checkmark$ " include stretching/bending from borate species).

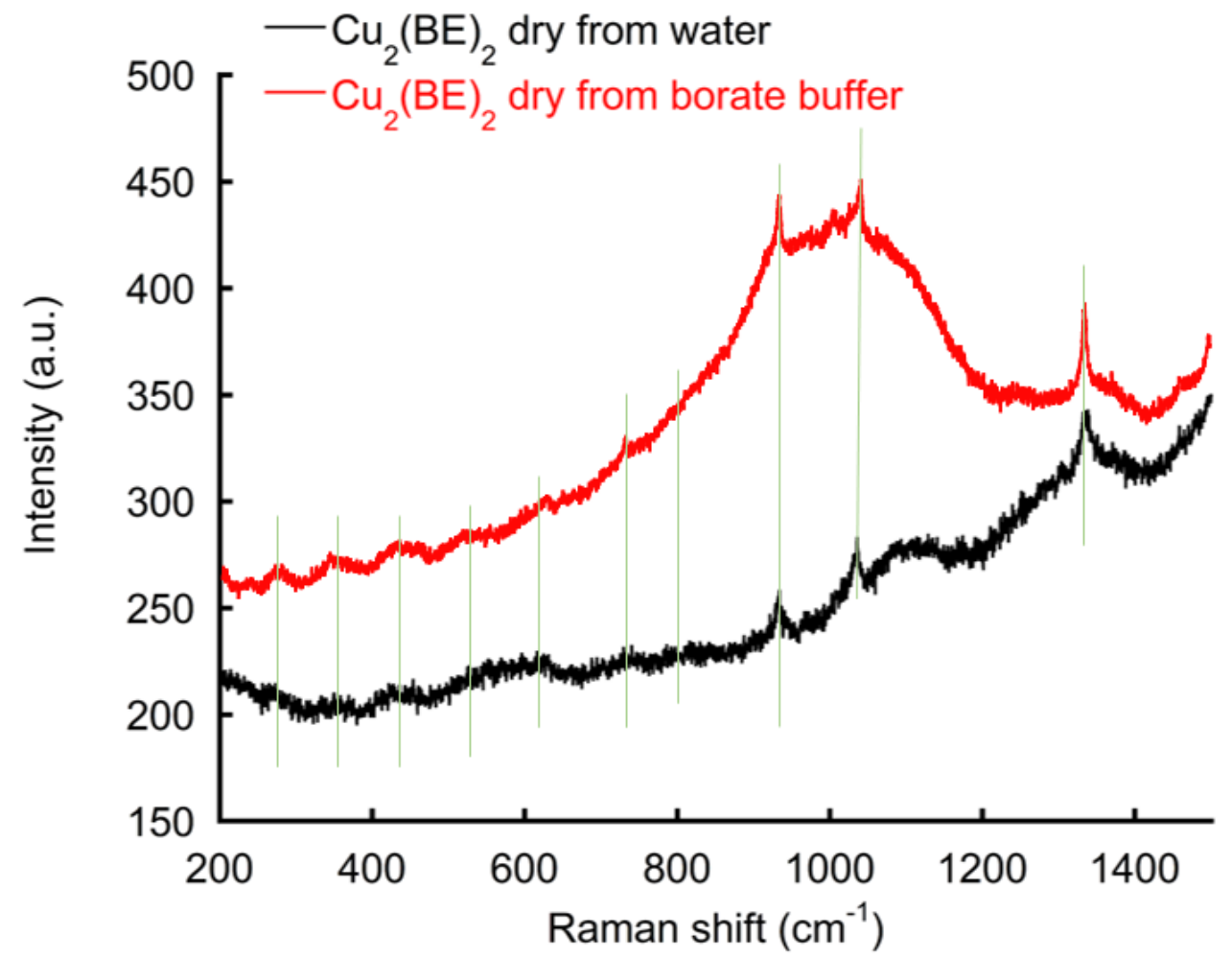

Figure S33. Raman spectroscopy of peptoid $\mathbf{B E}$ and complex $\mathrm{Cu}_{2}(\mathbf{B E})_{2}$ dried from different solution. 

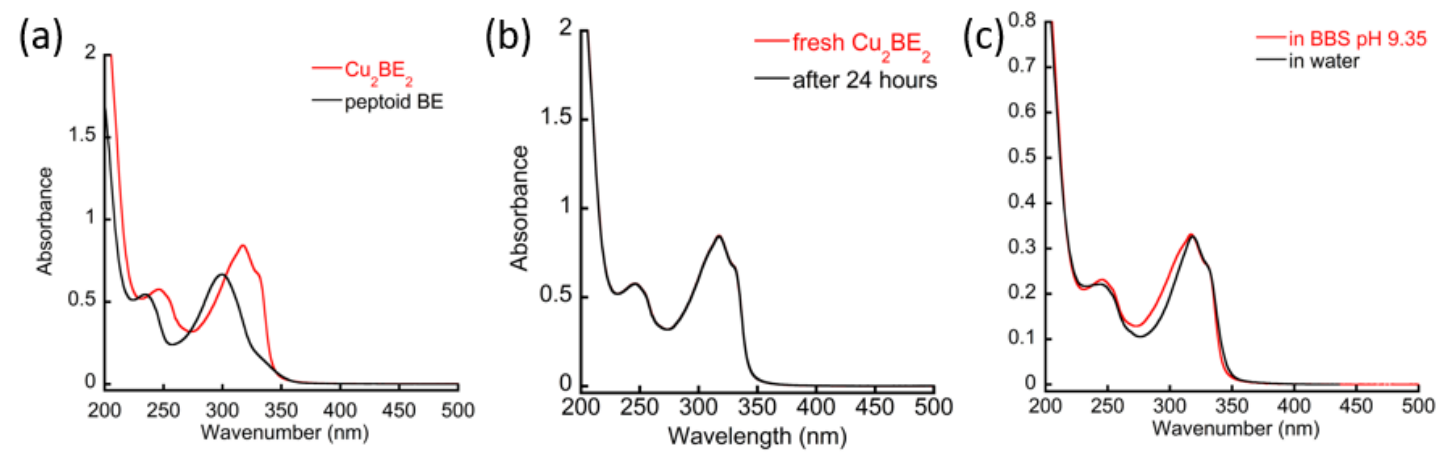

Figure S34. (a) UV-Vis of $\mathbf{B E}$ and $\mathrm{Cu}_{2}(\mathbf{B E})_{2}$ in $0.2 \mathrm{M}$ borate buffer at $\mathrm{pH} 9.35$; (b) UV-Vis of $\mathrm{Cu}_{2}(\mathbf{B E})_{2}$ in borate buffer for 24 hours; (c) UV-Vis of different concentrations of $\mathrm{Cu}_{2}(\mathbf{B E})_{2}$ in borate buffer and water.
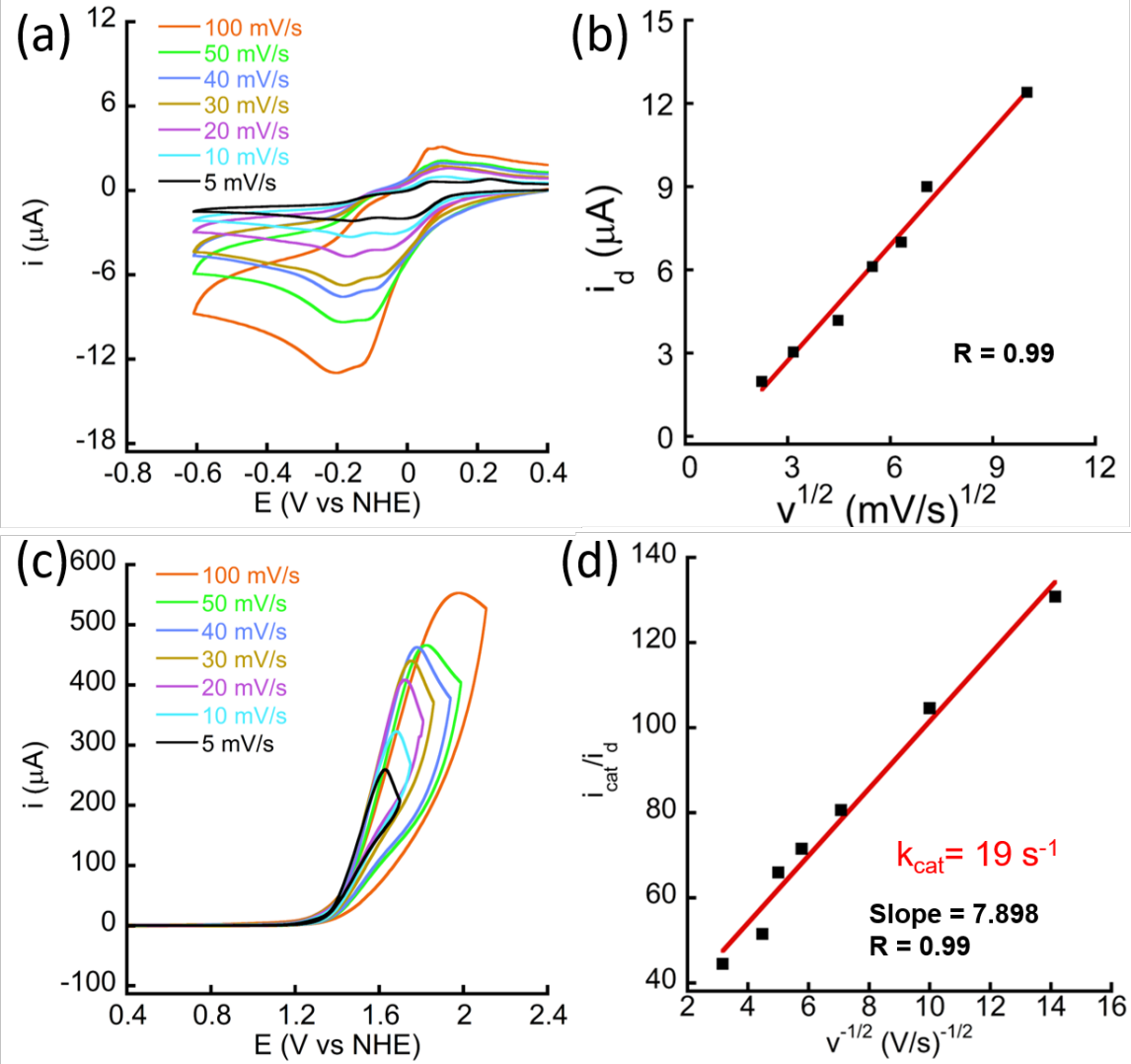

Figure $\mathrm{S} 35$. (a) $\mathrm{CVs}$ of $0.5 \mathrm{mM} \mathrm{Cu} 2(\mathbf{B E})_{2}$ at different scan rates with a narrow scanning range (-0.3 to $0.6 \mathrm{~V}$ vs NHE); (b) inserted is the linear regression of $i_{d}$ versus $v^{1 / 2}$; (c) CVs of 0.5 $\mathrm{mM} \mathrm{Cu}_{2}(\mathbf{B E})_{2}$ at different scan rates large scanning range (0.4 to $1.9 \mathrm{~V}$ vs NHE); (d) Linear regression of $\mathrm{i}_{\text {cat }} / \mathrm{i}_{\mathrm{d}}$ versus $\mathrm{v}^{-1 / 2}$. All experiments were performed in $0.2 \mathrm{M}$ borate buffer at $\mathrm{pH}$ 9.35 . 

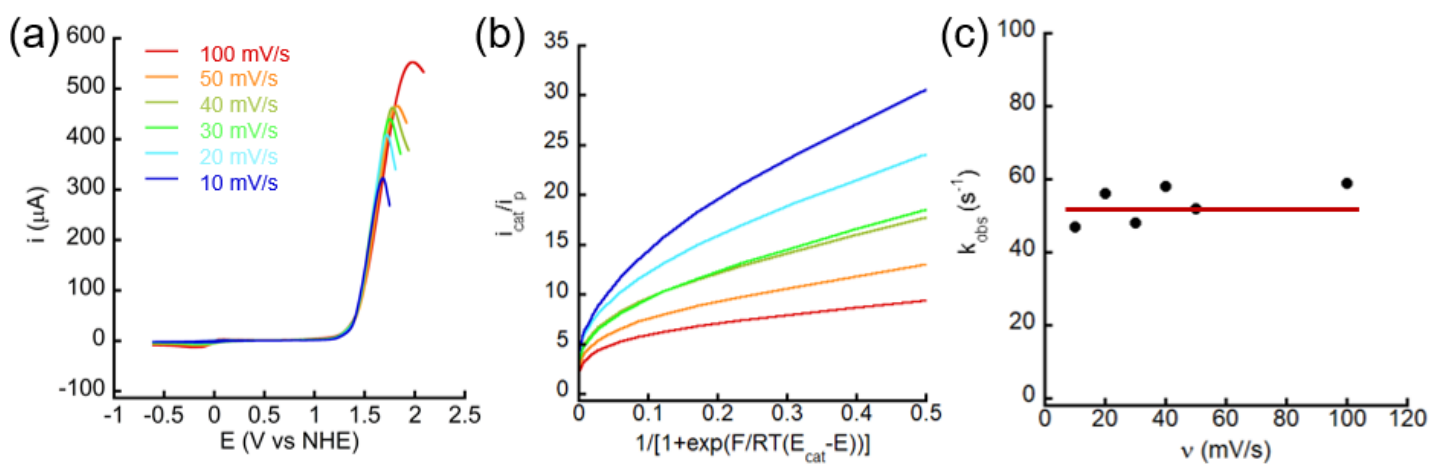

Figure S36. (a) CVs of $\mathrm{Cu}_{2}(\mathbf{B E})_{2}$ at different scan rates in $0.2 \mathrm{M}$ borate buffer at $\mathrm{pH} 9.35$, using glassy carbon working electrode; (b) FOWA plotting $i_{\text {cat }} / i_{\mathrm{p}}$ v. $1 /\left(1+\exp \left[\left(E_{\mathrm{cat}}-E\right) \mathrm{F} / \mathrm{RT}\right]\right)$ at each scan rate. (c) Plot of reaction kinetics $\left(k_{\mathrm{obs}}\right)$ extracted from FOWA. The red line represents the averaged $\mathrm{k}_{\text {obs }}$ of catalyst $\mathrm{Cu}_{2}(\mathbf{B E})_{2}, 51 \mathrm{~s}^{-1}$, obtained from the mean of 59, 52, 58, $48,56,47 \mathrm{~s}^{-1}$ at scan rates $100,50,40,30,20,10 \mathrm{mV} / \mathrm{s}$, respectively.

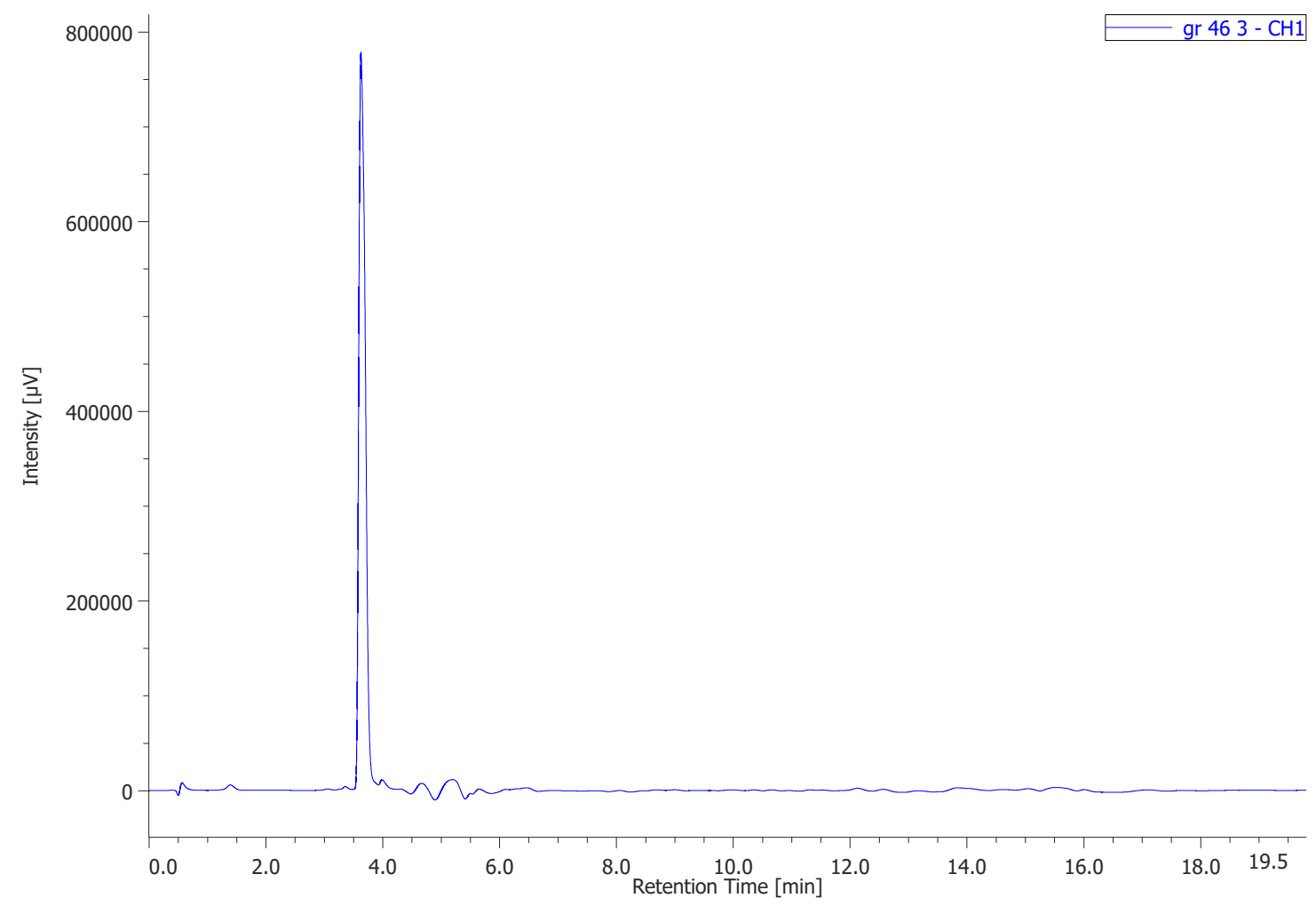

Figure S37. Analytical HPLC of purified peptoid BPE in water/acetonitrile with $0.1 \%$ TFA. 

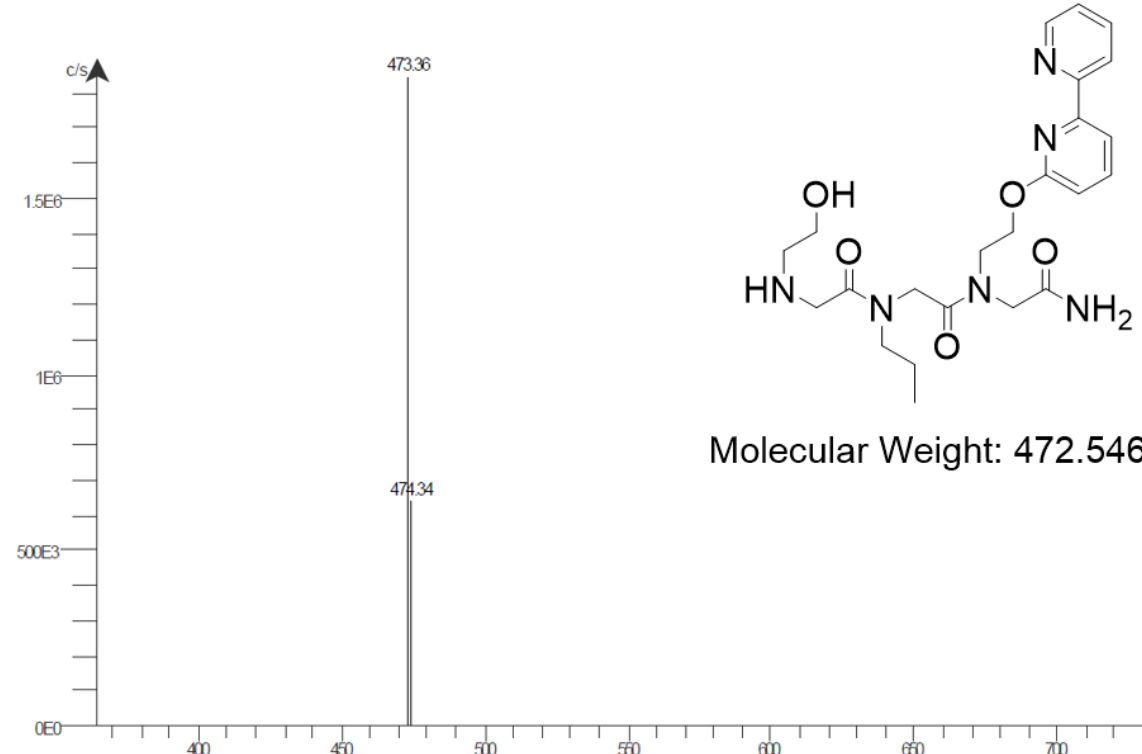

Molecular Weight: 472.5460

Figure S38. ESI-MS of purified peptoid BPE in water, $\mathrm{m} / \mathrm{z}\left(\mathbf{B P E}+\mathrm{H}^{+}\right)=473.30$.

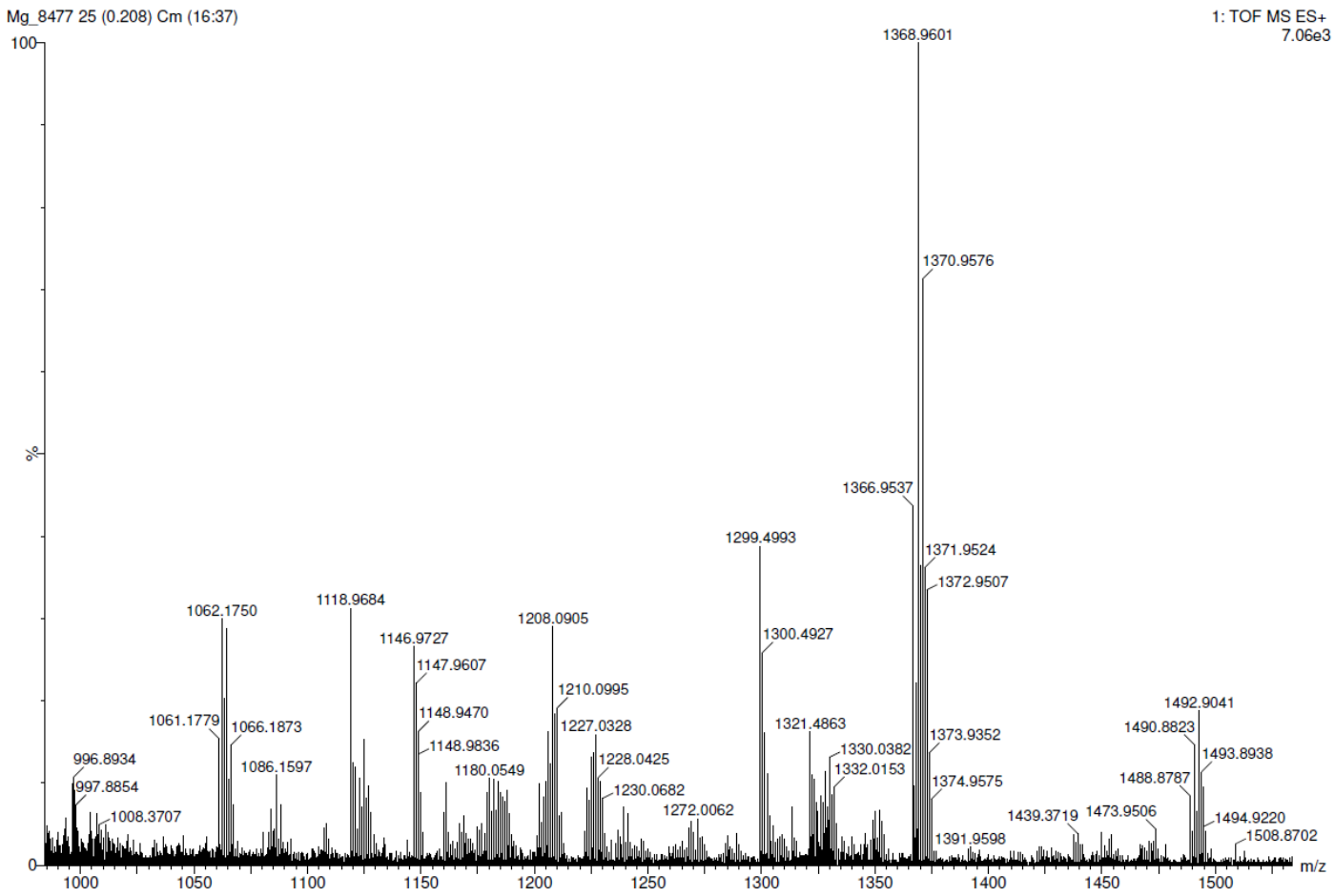




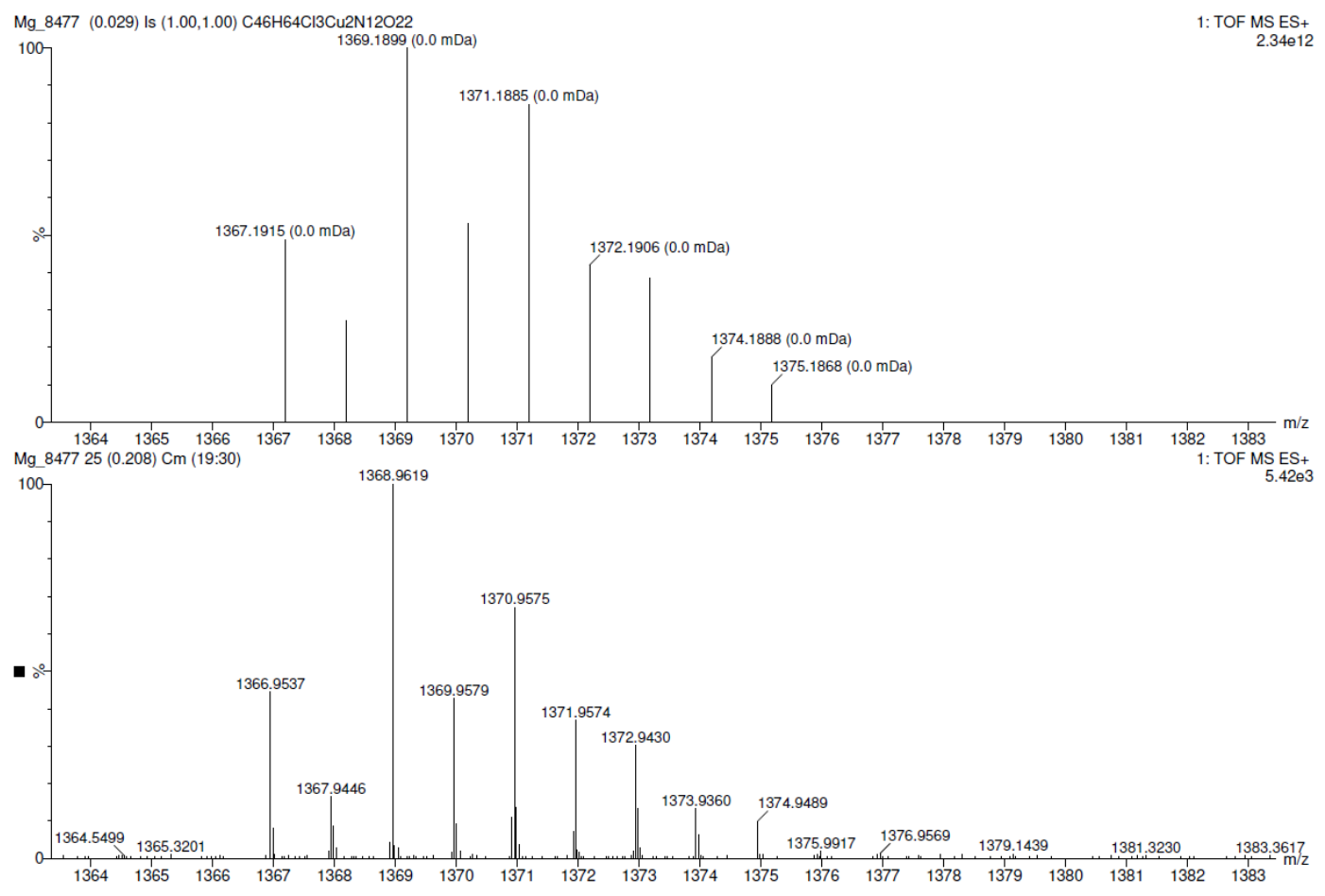

Figure S39. Top (page 26): ESI-MS of $\mathrm{Cu}_{2}(\mathbf{B P E})_{2} ; \mathrm{m} / \mathrm{z}\left[\left(\mathrm{Cu}_{2}(\mathbf{B P E})_{2}\right)\left(\mathrm{ClO}_{4}\right)_{3}=1366.9537\right.$; bottom: the simulated spectra of $\left[\left(\mathrm{Cu}_{2}(\mathbf{B P E})_{2}\right)\left(\mathrm{ClO}_{4}\right)_{3}\right.$.
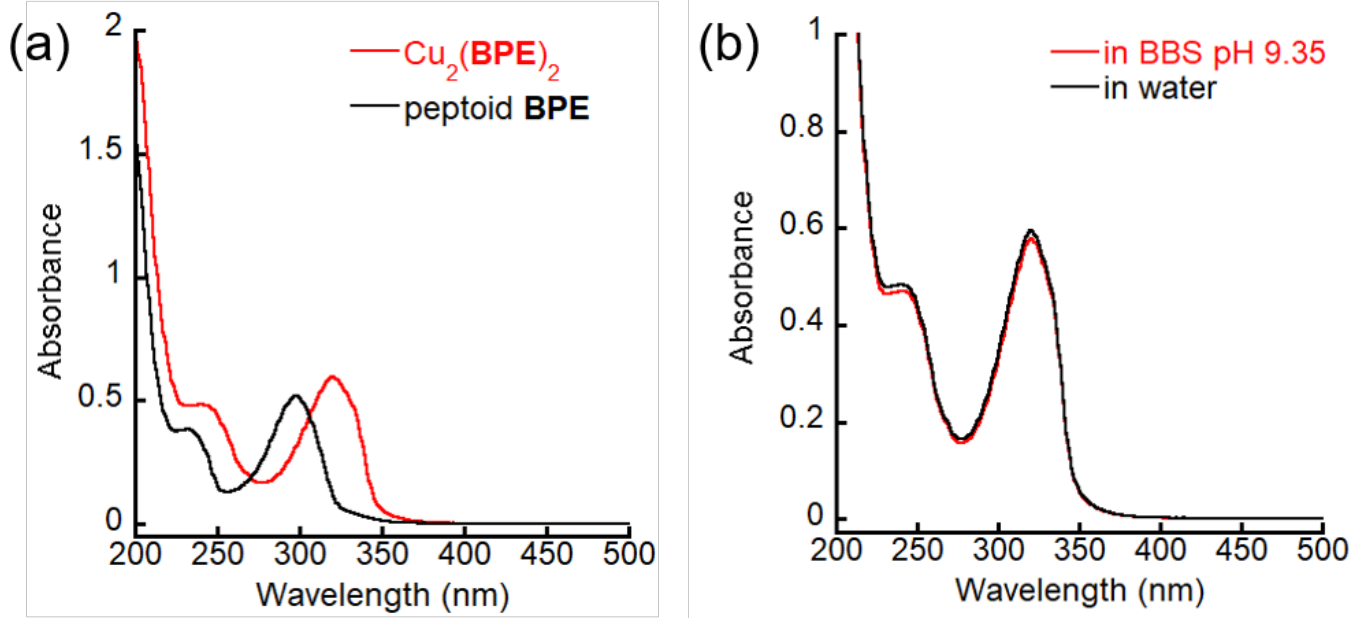

Figure S40. (a) UV-Vis of $\mathbf{B P E}$ and $\mathrm{Cu}_{2}(\mathbf{B P E})_{2}$ in $0.2 \mathrm{M}$ borate buffer at $\mathrm{pH} 9.35$; (b) UV-Vis of different concentrations of $\mathrm{Cu}_{2}(\mathbf{B P E})_{2}$ in borate buffer and water. 

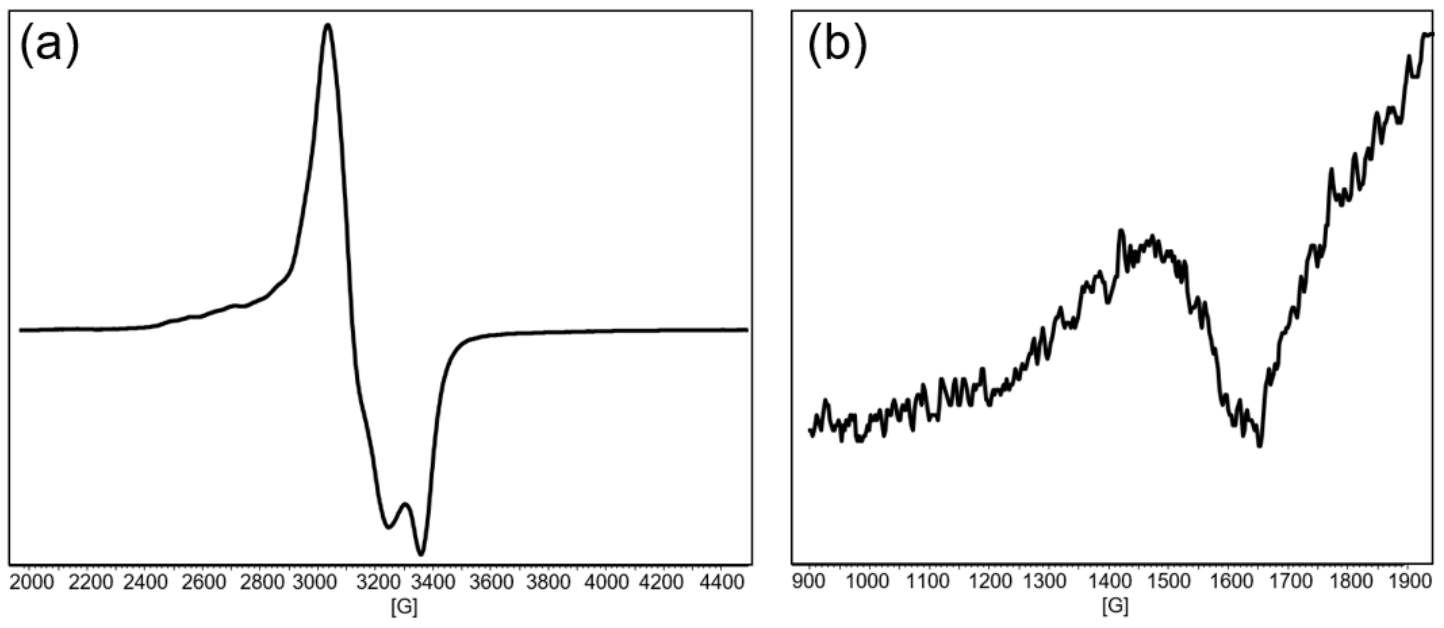

Figure S41. EPR of (a) $\mathrm{Cu}_{2}(\mathbf{B P E})_{2}$ powder and (b) a solution of $0.5 \mathrm{mM} \mathrm{Cu}_{2}(\mathbf{B P E})_{2}$ in $0.2 \mathrm{M}$ borate buffer at $\mathrm{pH} 9.35$; the solid phase measurement was done at room temperature ( $298 \mathrm{~K})$ and the solution phase measurement was done at $200 \mathrm{~K}$.
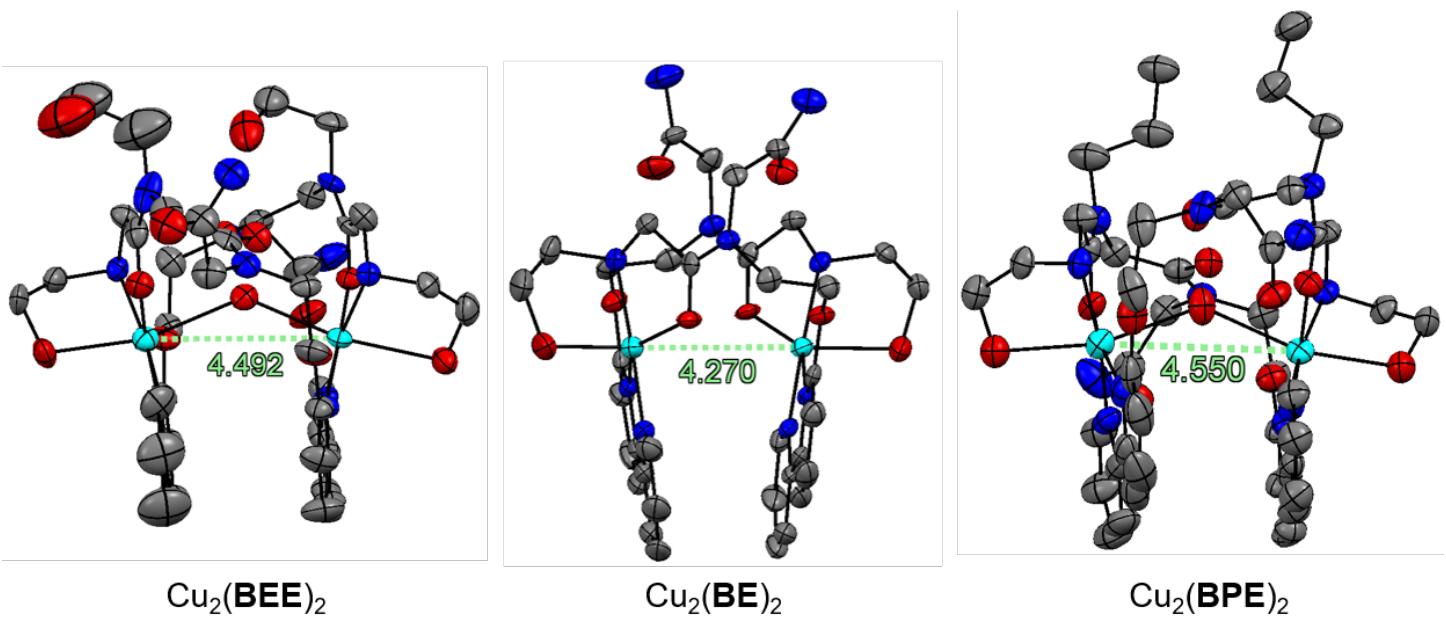

Figure $\mathrm{S} 42 . \mathrm{Cu}-\mathrm{Cu}$ distance comparison among three dinuclear $\mathrm{Cu}$ complexes; unit for distance is $\AA$. 


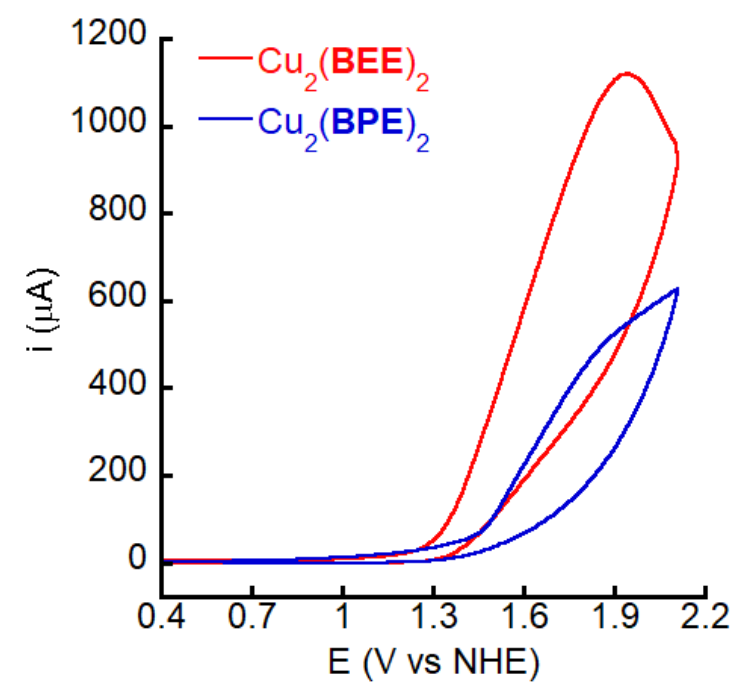

Figure S43. CVs of $1 \mathrm{mM}$ of $\mathrm{Cu}_{2} \mathbf{B E E} \mathbf{E}_{2}$ and $\mathrm{Cu}_{2} \mathbf{B E}_{2}$ in $0.2 \mathrm{M}$ borate buffer at $\mathrm{pH} 9.35$.

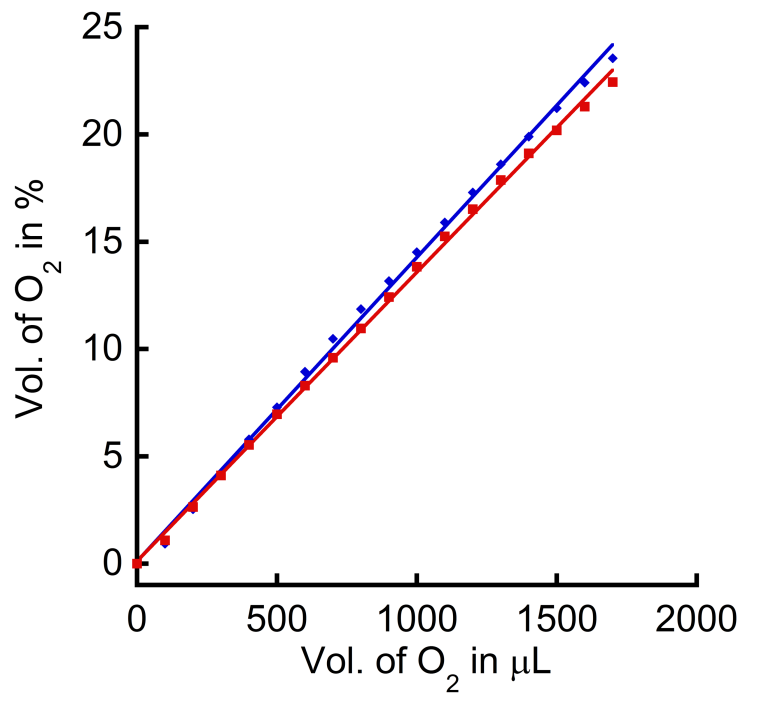

Figure S44. Calibration curve for the measure of evolved $\mathrm{O} 2$ in $\mu \mathrm{L}$ from $\%$. [Red line $=$ experiment 1 and blue line = experiment 2 and then take the average]. 


\section{Supporting Equations}

$$
\frac{i_{\text {cat }}}{i_{p}}=\frac{2.24 n \sqrt{\frac{R T k_{o b s}}{F v}}}{1+\exp \left[\frac{\mathrm{F}}{\mathrm{RT}}\left(E_{\text {cat }}-E\right)\right]}
$$

The formula used to obtain $\mathrm{k}_{\text {obs }}$ by Foot-of-the-wave analysis (FOWA): ${ }^{4}$

- $\mathrm{E}_{\mathrm{cat}}$ - the standard potential for the catalysis-initiating redox couple calculated from $\mathrm{CV}$.

- $\mathrm{i}_{\text {cat }}$ - the catalytic current intensity in the presence of substrate.

- $\mathrm{i}_{\mathrm{p}}$ - the non-catalytic current intensity.

- $\mathrm{n}=4$ (for water oxidation) the number of electrons in the reaction.

- $\mathrm{F}=96485 \mathrm{C} / \mathrm{mol}, \mathrm{R}=8.314 \mathrm{~J} / \mathrm{mol} \bullet \mathrm{K}, \mathrm{T}=298 \mathrm{~K}, v-$ scan rate in $\mathrm{V} / \mathrm{s}$.

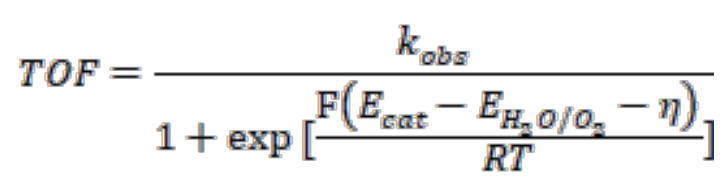
.eq.S4

The formula used to obtain TOF-overpotential $(\eta)$ relationship (Figure 9 in paper): ${ }^{4}$

- $\mathrm{k}_{\mathrm{obs}}$ - the TOF value calculated via FOWA in Figure S29.

- $\mathrm{E}_{\mathrm{cat}}$ - the standard potential for the catalysis-initiating redox couple calculated from CV.

- $\mathrm{E}_{\mathrm{H} 2 \mathrm{O} / 02}$ - the thermodynamic potential of water oxidation at $\mathrm{pH} 9.35$.

- $\mathrm{F}=96485 \mathrm{C} / \mathrm{mol}, \mathrm{R}=8.314 \mathrm{~J} / \mathrm{mol} \bullet \mathrm{K}, \mathrm{T}=298 \mathrm{~K}, v-$ scan rate in $\mathrm{V} / \mathrm{s}$. 


\section{Supporting Tables}

Table S1. Summary of TOF values with different methods by $\mathrm{Cu}$-based WOCs for homogeneous water oxidation at various $\mathrm{pH}$ and buffer conditions.

\begin{tabular}{|c|c|c|c|c|c|}
\hline & $\mathrm{k}_{\mathrm{cat}}{ }^{\mathrm{a}}\left(\mathrm{s}^{-1}\right)$ & $\mathrm{k}_{\mathrm{obs}}{ }^{\mathrm{b}}\left(\mathrm{s}^{-1}\right)$ & Scan rate $(\mathrm{mV} / \mathrm{s})$ & Buffer \& pH & Ref. \\
\hline $\mathrm{Cu}_{2}(\mathbf{B E E})_{2}$ & 129 & 5503 & $5 \sim 200$ & BBS, ${ }^{\text {c } 9.35}$ & $\mathbf{t w}^{\mathrm{g}}$ \\
\hline $\mathrm{Cu}_{2}(\mathbf{B E})_{2}$ & 19 & 51 & 5 200 & BBS, 9.35 & tw \\
\hline $\mathrm{Cu}(\mathrm{BPy})(\mathrm{OH})_{2}$ & 100 & 1 & $1 \sim 5$ & ABS, ${ }^{\mathrm{d}} 12.5$ & 5 \\
\hline $\mathrm{Cu}\left[\mathrm{BPy}(\mathrm{OH})_{2}\right](\mathrm{OH})_{2}$ & 0.4 & 1 & $2 \sim 20$ & ABS, 12.4 & 6 \\
\hline $\mathrm{Cu}(\text { pyalk })_{2}$ & 0.7 & 1 & $5 \sim 100$ & $\mathrm{KNO}_{3} / \mathrm{KOH}, 12.5$ & 7 \\
\hline $\mathrm{Cu}($ pimH $)$ & 35 & 1 & $5 \sim 100$ & ABS, 12 & 8 \\
\hline $\mathrm{Cu}\left(\mathrm{L}_{\mathrm{Gly}} / \mathrm{L}_{\mathrm{Glu}}\right)$ & $105 \sim 267$ & 1 & $25 \sim 125$ & PBS, ${ }^{\text {e }} 12$ & 9 \\
\hline $\mathrm{Cu}(\mathrm{TGG})\left(\mathrm{H}_{2} \mathrm{O}\right)$ & 33 & 1 & $5 \sim 40$ & PBS, 11.5 & 10 \\
\hline $\mathrm{Cu}(\mathrm{L} 1 \sim \mathrm{L} 4)$ & 1 & $0.16 \sim 3.58$ & $5 \sim 100$ & PBS, 11.5 & 11 \\
\hline $\mathrm{Cu}(\mathrm{BPT})(\mathrm{OH})_{2}$ & 1 & 5.8 & $2 \sim 100$ & PBS, 11.5 & 12 \\
\hline $\mathrm{Cu}$ (peptides) & $24 \sim 53$ & 1 & $5 \sim 60$ & PBS, 11 & 13 \\
\hline $\mathrm{Cu}\left(\right.$ pincer- $\left.\mathrm{CO}_{3} \mathrm{H}\right)$ & 20.1 & 1 & $10 \sim 50$ & $\mathrm{CBS},{ }^{\mathrm{f}} 10$ & 14 \\
\hline $\mathrm{Cu}(\mathrm{TMC})\left(\mathrm{H}_{2} \mathrm{O}\right)$ & 30 & 1 & $10 \sim 500$ & PBS, 7 & 15 \\
\hline $\mathrm{Cu}\left(\mathrm{PPy}_{3}\right)$ & 20 & 1 & $10 \sim 250$ & PBS, 8 & 16 \\
\hline $\mathrm{Cu}(\mathrm{L} 1 \mathrm{H})(\mathrm{L} 1)\left(\mathrm{H}_{2} \mathrm{O}\right)$ & 1 & 100 & $10 \sim 50$ & PBS, 7 & 17 \\
\hline $\mathrm{Cu}$ (porphrin) & 30 & $\sim 5$ & $10 \sim 60$ & PBS, 7 & 18 \\
\hline $\mathrm{Cu}_{2}(\mathrm{BPMAN})(\mu-\mathrm{OH})$ & 0.6 & 1 & $5 \sim 60$ & PBS, 7 & 19 \\
\hline $\mathrm{Cu}(\mathrm{TPA})\left(\mathrm{H}_{2} \mathrm{O}\right)$ & 0.1 & 1 & $5 \sim 100$ & PBS, 7 & 20 \\
\hline $\mathrm{Cu}(\mathrm{L} 1 \sim \mathrm{L} 3)$ & 1 & $3.6 \sim 140$ & 100 & PBS, 7 & 21 \\
\hline
\end{tabular}

a: calculated by considering the peak current value; b: calculated by FOWA (foot-of-the-wave analysis); c: BBS, borate buffer solution; d: ABS, acetate buffer solution; e: PBS, phosphate buffer solution; f: CBS, carbonate buffer solution; g: tw, this work. 
Table S2: Crystal data of complexes $\mathrm{Cu}_{2}(\mathbf{B E E})_{2}, \mathrm{Cu}_{2}(\mathbf{B E})_{2}, \mathrm{Cu}_{2}(\mathbf{B P E})_{2}$.

\begin{tabular}{|c|c|c|c|}
\hline Complex & $\mathrm{Cu}_{2}(\mathbf{B E E})_{2}$ & $\mathrm{Cu}_{2}(\mathbf{B E})_{2}$ & $\mathrm{Cu}_{2}(\mathbf{B P E})_{2}$ \\
\hline Formula & $\mathrm{C}_{88} \mathrm{H}_{130} \mathrm{Cl}_{8} \mathrm{Cu}_{4} \mathrm{~N}_{24} \mathrm{O}_{69}$ & $\mathrm{C}_{40} \mathrm{H}_{52} \mathrm{Cl}_{4} \mathrm{Cu}_{2} \mathrm{~N}_{12} \mathrm{O}_{24}$ & $\mathrm{C}_{48} \mathrm{H}_{69} \mathrm{Cl}_{4} \mathrm{Cu}_{2} \mathrm{~N}_{13} \mathrm{O}_{27}$ \\
\hline Formula weight & 3165.91 & 1353.81 & 1529.07 \\
\hline$T(\mathrm{~K})$ & $100(2)$ & $200(2)$ & $200(2)$ \\
\hline Crystal color & blue & blue & blue \\
\hline Crystal system & monoclinic & monoclinic & triclinic \\
\hline Space group & $C 2 / c$ & $P 21 / c$ & $P-1$ \\
\hline$a(\AA)$ & $43.701(7)$ & $12.119(2)$ & $13.800(2)$ \\
\hline$b(\AA)$ & $14.364(3)$ & $12.6992(2)$ & $15.635(2)$ \\
\hline$c(\AA)$ & $23.774(4)$ & $36.289(4)$ & $16.505(2)$ \\
\hline$\alpha\left(^{\circ}\right)$ & 90 & 90 & $75.627(2)$ \\
\hline$\beta\left(^{\circ}\right)$ & $115.874(4)$ & $98.197(3)$ & $73.025(3)$ \\
\hline$\gamma\left({ }^{\circ}\right)$ & 90 & 90 & $76.260(4)$ \\
\hline$V\left(\AA^{3}\right)$ & $13427(4)$ & $5528.2(2)$ & $3246.6(8)$ \\
\hline$Z$ & 4 & 4 & 2 \\
\hline $\begin{array}{c}\text { Crystal } \\
\text { dimensions }(\mathrm{mm})\end{array}$ & $0.24 \times 0.12 \times 0.09$ & $0.24 \times 0.18 \times 0.15$ & $0.24 \times 0.15 \times 0.09$ \\
\hline$D_{\mathrm{c}}\left(\mathrm{g} \mathrm{cm}^{-3}\right)$ & 1.566 & 1.627 & 1.564 \\
\hline$F(000)$ & 6520 & 2776 & 1580 \\
\hline$\lambda(\operatorname{Mo~K} \alpha)(\AA)$ & 0.71073 & 0.71073 & 0.71073 \\
\hline$\theta$ Range $\left(^{\circ}\right)$ & $1.660-25.121$ & $1.698-24.435$ & $1.315-24.238$ \\
\hline $\begin{array}{l}\text { Absorption } \\
\text { correction }\end{array}$ & multi-scan & multi-scan & multi-scan \\
\hline$R$ factor $(\%)$ & 8.6 & 4.62 & 6.61 \\
\hline $\begin{array}{c}w R_{2} \text { index } \\
\text { (reflections) }\end{array}$ & 0.2524 & 0.0936 & 0.1626 \\
\hline Goodness-of-fit & 0.930 & 0.844 & 1.000 \\
\hline
\end{tabular}



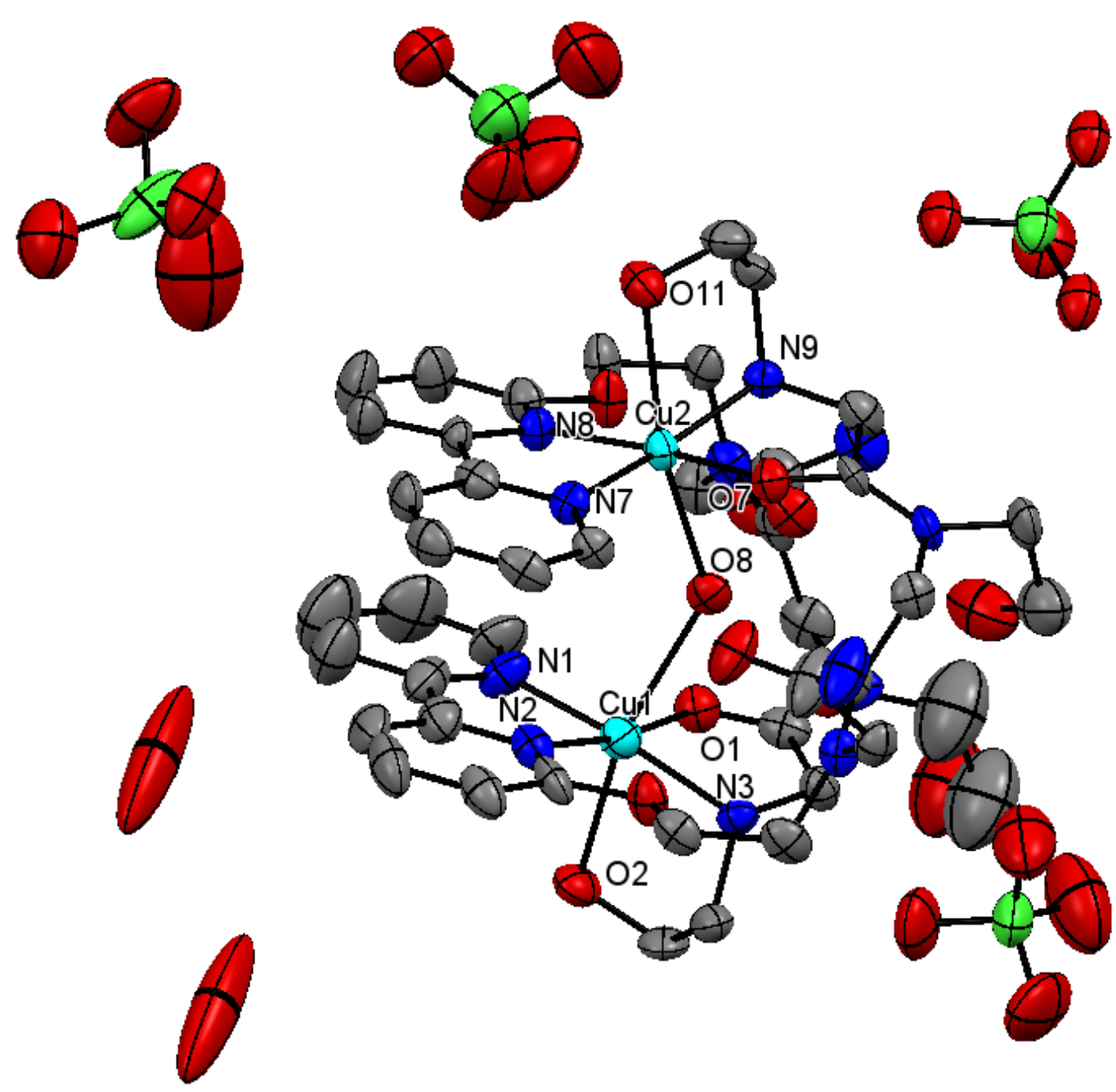

Figure S45. Crystal structure of complex $\mathrm{Cu}_{2}(\mathbf{B E E})_{2}$, hydrogen atoms and part of water guest molecules are omitted for clarity. 
Table S3: Selected Bond length for $\mathrm{Cu}_{2}(\mathbf{B E E})_{2}$.

\begin{tabular}{|l|l|l|l|}
\hline Bond type & Length $(\AA)$ & Bond type & Length $(\AA)$ \\
\hline $\mathrm{Cu} 1 \mathrm{~N} 1$ & $1.972(8)$ & $\mathrm{Cu} 2 \mathrm{~N} 8$ & $2.034(7)$ \\
\hline $\mathrm{Cu} 1 \mathrm{O} 1$ & $1.989(6)$ & $\mathrm{Cu} 2 \mathrm{~N} 7$ & $1.978(7)$ \\
\hline $\mathrm{Cu} 1 \mathrm{~N} 3$ & $2.012(7)$ & $\mathrm{Cu} 2 \mathrm{~N} 9$ & $2.012(6)$ \\
\hline $\mathrm{Cu} 1 \mathrm{~N} 2$ & $2.041(7)$ & $\mathrm{Cu} 2 \mathrm{O} 8$ & $2.405(6)$ \\
\hline $\mathrm{Cu} 1 \mathrm{O} 2$ & $2.363(6)$ & $\mathrm{Cu} 2-\mathrm{O} 11$ & 2.484 \\
\hline $\mathrm{Cu} 1-\mathrm{O} 8$ & 2.479 & $\mathrm{Cu} 2 \mathrm{O} 7$ & $1.978(5)$ \\
\hline
\end{tabular}

Table S4: Selected Bond Angles for $\mathrm{Cu}_{2}(\mathbf{B E E})_{2}$

\begin{tabular}{|l|l|l|l|}
\hline Angle type & Angle $\left({ }^{\circ}\right)$ & Angle type & Angle $\left(^{\circ}\right)$ \\
\hline N1 Cu1 O1 & $91.9(3)$ & O7 Cu2 N7 & $90.4(3)$ \\
\hline N1 Cu1 N3 & $169.6(3)$ & O7 Cu2 N9 & $82.9(2)$ \\
\hline O1 Cu1 N3 & $82.4(3)$ & N7 Cu2 N9 & $168.2(3)$ \\
\hline N1 Cu1 N2 & $81.1(3)$ & O7 Cu2 N8 & $171.9(3)$ \\
\hline O1 Cu1 N2 & $171.2(3)$ & N7 Cu2 N8 & $81.6(3)$ \\
\hline N3 Cu1 N2 & $105.2(3)$ & N9 Cu2 N8 & $105.2(3)$ \\
\hline N1 Cu1 O2 & $90.5(3)$ & O7 Cu2 O8 & $84.7(2)$ \\
\hline O1 Cu1 O2 & $87.3(2)$ & N7 Cu2 O8 & $101.5(2)$ \\
\hline N3 Cu1 O2 & $80.5(3)$ & N9 Cu2 O8 & $87.5(2)$ \\
\hline N2 Cu1 O2 & $98.2(3)$ & N8 Cu2 O8 & $95.6(2)$ \\
\hline
\end{tabular}




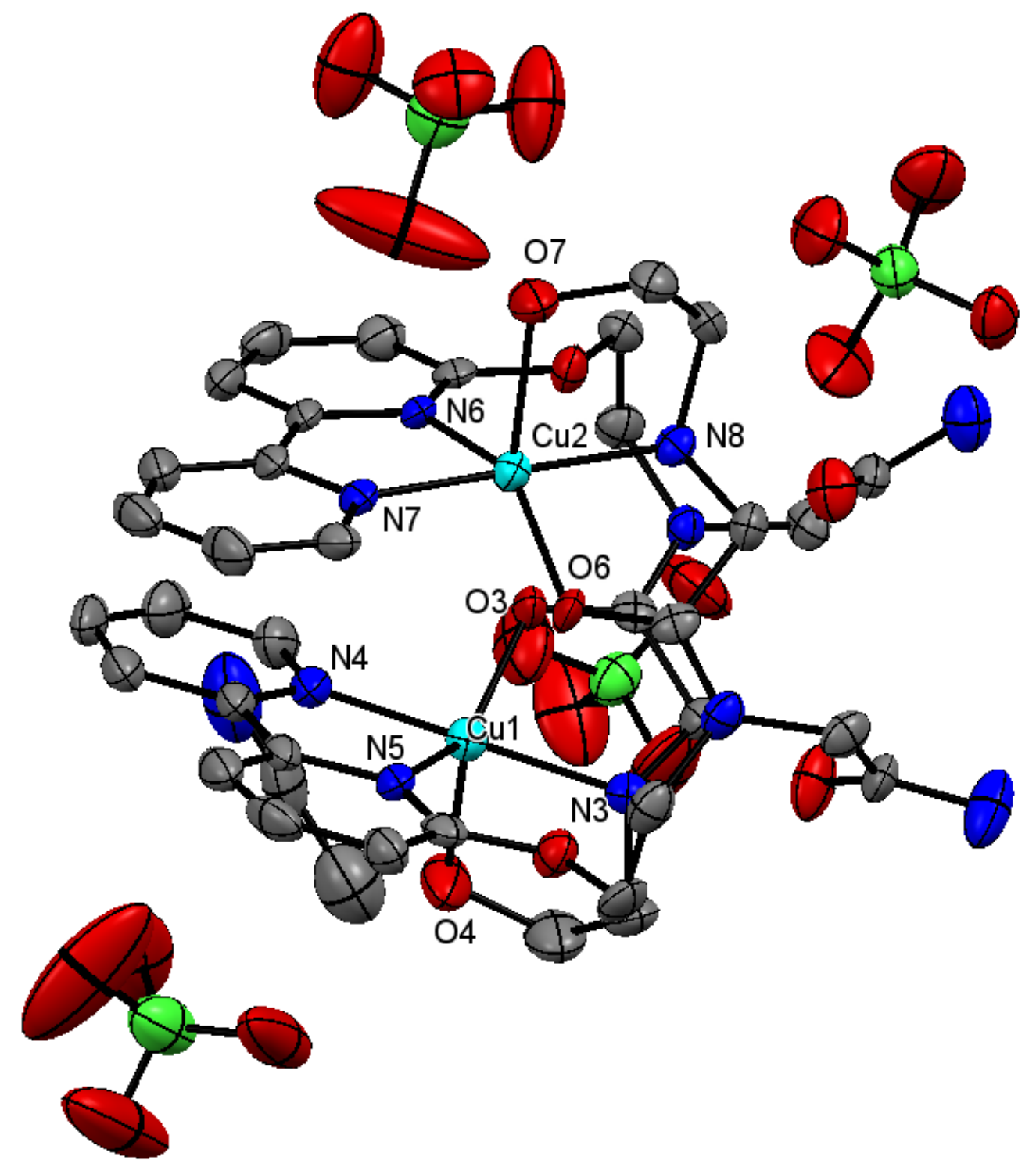

Figure S46. Crystal structure of complex $\mathrm{Cu}_{2}(\mathbf{B E})_{2}$, hydrogen atoms are omitted for clarity. 
Table S5: Selected Bond length for $\mathrm{Cu}_{2}(\mathbf{B E})_{2}$

\begin{tabular}{|l|l|l|l|}
\hline Bond type & Length $(\AA)$ & Bond type & Length $(\AA)$ \\
\hline Cu1 N5 & $2.044(4)$ & $\mathrm{Cu} 2 \mathrm{~N} 6$ & $2.038(4)$ \\
\hline Cu1 N3 & $1.987(3)$ & $\mathrm{Cu} 2 \mathrm{~N} 8$ & $1.990(3)$ \\
\hline Cu1 N4 & $1.955(4)$ & $\mathrm{Cu} 2 \mathrm{~N} 7$ & $1.967(4)$ \\
\hline Cu1 O3 & $1.960(3)$ & $\mathrm{Cu} 2 \mathrm{O} 6$ & $1.950(3)$ \\
\hline Cu1 O4 & $2.157(4)$ & $\mathrm{Cu} 2 \mathrm{O} 7$ & $2.260(3)$ \\
\hline
\end{tabular}

Table S6: Selected Bond Angles for $\mathrm{Cu}_{2}(\mathbf{B E})_{2}$

\begin{tabular}{|l|l|l|l|}
\hline Angle type & Angle $\left({ }^{\circ}\right)$ & Angle type & Angle $\left({ }^{\circ}\right)$ \\
\hline N4 Cu1 O3 & $91.38(15)$ & O6 Cu2 N7 & $91.05(14)$ \\
\hline N4 Cu1 N3 & $170.34(17)$ & O6 Cu2 N8 & $83.92(13)$ \\
\hline O3 Cu1 N3 & $83.70(13)$ & N7 Cu2 N8 & $170.51(16)$ \\
\hline N4 Cu1 N5 & $80.94(16)$ & O6 Cu2 N6 & $143.45(14)$ \\
\hline O3 Cu1 N5 & $141.33(14)$ & N7 Cu2 N6 & $81.49(16)$ \\
\hline N3 Cu1 N5 & $108.05(15)$ & N8 Cu2 N6 & $107.30(15)$ \\
\hline N4 Cu1 O4 & $91.71(15)$ & O6 Cu2 O7 & $119.26(13)$ \\
\hline O3 Cu1 O4 & $109.55(15)$ & N7 Cu2 O7 & $93.62(13)$ \\
\hline N3 Cu1 O4 & $82.17(14)$ & N8 Cu2 O7 & $81.93(13)$ \\
\hline N5 Cu1 O4 & $108.52(15)$ & N6 Cu2 O7 & $96.99(13)$ \\
\hline
\end{tabular}



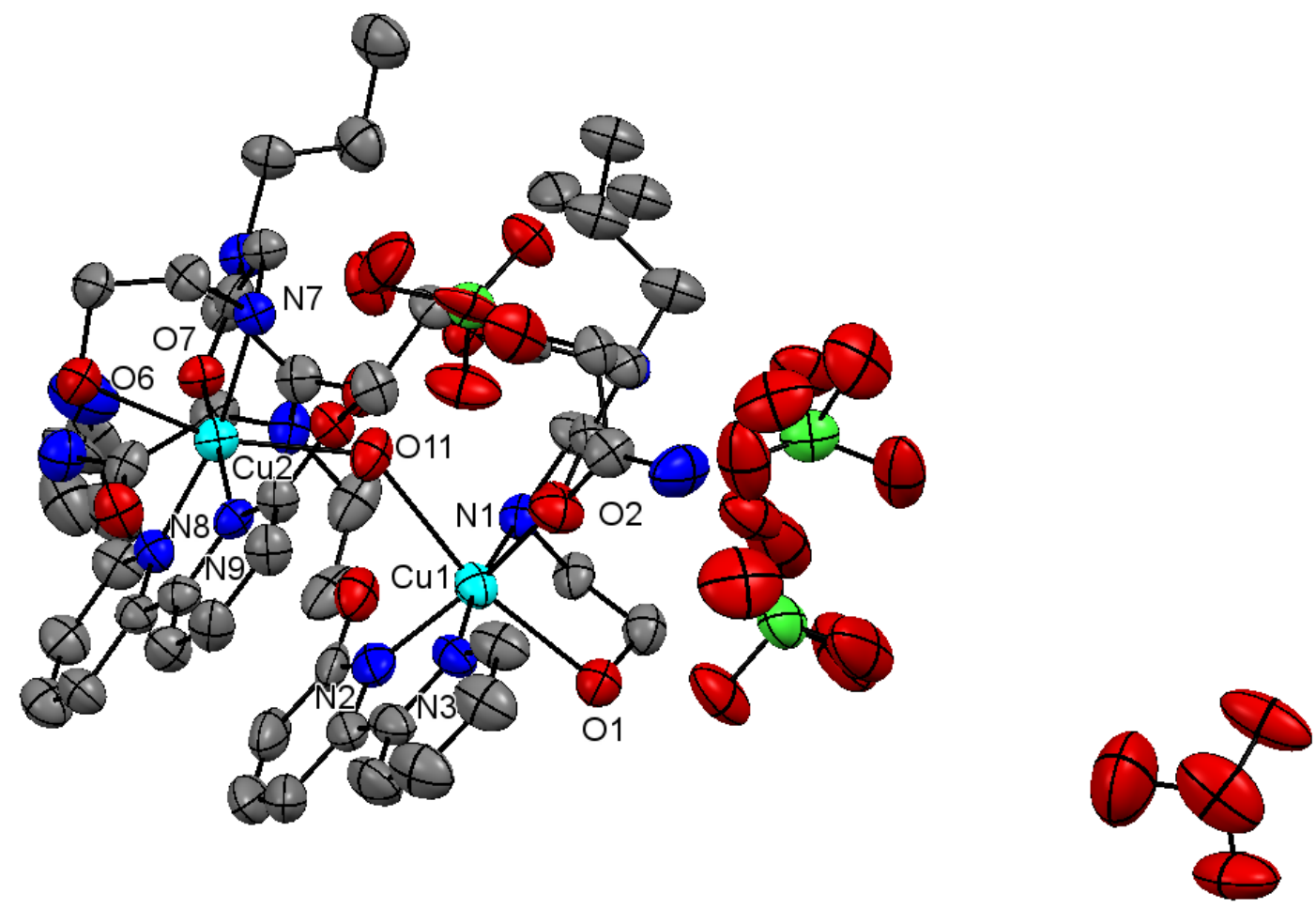

Figure S47. Crystal structure of complex $\mathrm{Cu}_{2}(\mathbf{B P E})_{2}$, hydrogen atoms are omitted for clarity. 
Table S7: Selected Bond length for $\mathrm{Cu}_{2}(\mathbf{B P E})_{2}$.

\begin{tabular}{|l|l|l|l|}
\hline Bond type & Length $(\AA)$ & Bond type & Length $(\AA)$ \\
\hline Cu1 N1 & $2.020(7)$ & $\mathrm{Cu} 2 \mathrm{~N} 8$ & $1.969(7)$ \\
\hline $\mathrm{Cu} 1 \mathrm{O} 1$ & $2.422(5)$ & $\mathrm{Cu} 2 \mathrm{~N} 7$ & $2.016(7)$ \\
\hline $\mathrm{Cu} 1 \mathrm{~N} 3$ & $1.966(7)$ & $\mathrm{Cu} 2 \mathrm{~N} 9$ & $2.032(6)$ \\
\hline $\mathrm{Cu} 1 \mathrm{~N} 2$ & $2.003(7)$ & $\mathrm{Cu} 2 \mathrm{O} 6$ & $2.331(5)$ \\
\hline $\mathrm{Cu} 1 \mathrm{O} 2$ & $1.942(6)$ & $\mathrm{Cu} 2-\mathrm{O} 11$ & $2.461(6)$ \\
\hline $\mathrm{Cu} 1-\mathrm{O} 11$ & $2.481(5)$ & $\mathrm{Cu} 2 \mathrm{O} 7$ & $1.979(5)$ \\
\hline
\end{tabular}

Table S8: Selected Bond Angles for $\mathrm{Cu}_{2}(\mathbf{B P E})_{2}$

\begin{tabular}{|l|l|l|l|}
\hline Angle type & Angle $\left({ }^{\circ}\right)$ & Angle type & Angle $\left(^{\circ}\right)$ \\
\hline $\mathrm{N} 3 \mathrm{Cu} 1 \mathrm{O} 2$ & $90.2(2)$ & O6 Cu2 N7 & $78.4(2)$ \\
\hline $\mathrm{N} 1 \mathrm{Cu} 1 \mathrm{~N} 3$ & $170.1(3)$ & O6 Cu2 N9 & $91.8(2)$ \\
\hline O1 Cu1 N1 & $77.9(2)$ & N7 Cu2 N8 & $168.4(3)$ \\
\hline N1 Cu1 N2 & $105.0(3)$ & O6 Cu2 N8 & $91.0(2)$ \\
\hline O1 Cu1 N2 & $96.1(2)$ & N9 Cu2 N8 & $81.5(2)$ \\
\hline N3 Cu1 N2 & $82.2(3)$ & N9 Cu2 N7 & $103.3(2)$ \\
\hline N1 Cu1 O2 & $83.7(2)$ & O6 Cu2 O7 & $92.5(2)$ \\
\hline O1 Cu1 O2 & $93.4(2)$ & N7 Cu2 O7 & $83.2(2)$ \\
\hline N3 Cu1 O1 & $94.8(2)$ & N9 Cu2 O7 & $172.8(2)$ \\
\hline N2 Cu1 O2 & $168.3(2)$ & N8 Cu2 O7 & $92.7(2)$ \\
\hline
\end{tabular}




\section{References}

1 Baskin, M.; Panz, L.; Maayan, G. Versatile Ruthenium Complexes Based on 2,2'-Bipyridine Modified Peptoids. Chem. Commun., 2016, 52, 10350-10353.

2 Green, T. W.; Wuts, P. G. M. Protective Groups in Organic Synthesis, Wiley-Interscience, New York, 1999, 127-141, 708-711.

3 Zuckermann, R. N., Kerr, J. M., Kent, S. B. W., Moos, W. H., Efficient method for the preparation of peptoids [oligo(N-substituted glycines)] by submonomer solid-phase synthesis, J. Am. Chem. Soc., 1992, 114, 10646.

4 (a) Costentin, C.; Savéant, J.-M., Multielectron, Multistep Molecular Catalysis of Electrochemical Reactions: Benchmarking of Homogeneous Catalysts. ChemElectroChem 2014, 1 (7), 1226-1236; (b) Costentin, C.; Drouet, S.; Robert, M.; Saveant, J. M., Turnover numbers, turnover frequencies, and overpotential in molecular catalysis of electrochemical reactions. Cyclic voltammetry and preparative-scale electrolysis. J Am Chem Soc 2012, 134 (27), 11235-42.

5 Barnett, S. M.; Goldberg, K. I.; Mayer, J. M., A soluble copper-bipyridine water-oxidation electrocatalyst. Nat Chem 2012, 4 (6), 498-502.

6 Zhang, T.; Wang, C.; Liu, S.; Wang, J. L.; Lin, W., A biomimetic copper water oxidation catalyst with low overpotential. J Am Chem Soc 2014, 136 (1), 273-81.

7 Fisher, K. J.; Materna, K. L.; Mercado, B. Q.; Crabtree, R. H.; Brudvig, G. W., Electrocatalytic Water Oxidation by a Copper(II) Complex of an Oxidation-Resistant Ligand. Acs Catal 2017, 7 (5), 3384-3387.

8 Stott, L. A.; Prosser, K. E.; Berdichevsky, E. K.; Walsby, C. J.; Warren, J. J., Lowering water oxidation overpotentials using the ionisable imidazole of copper(2-(2'-pyridyl) imidazole). Chem Commun 2017, 53 (3), 651-654.

9 Jiang, X.; Li, J.; Yang, B.; Wei, X. Z.; Dong, B. W.; Kao, Y.; Huang, M. Y.; Tung, C. H.; Wu, L. Z., A Bio-inspired Cu4O4 Cubane: Effective Molecular Catalysts for Electrocatalytic Water Oxidation in Aqueous Solution. Angew Chem Int Edit 2018, 57 (26), 7850-7854.

10 Zhang, M. T.; Chen, Z.; Kang, P.; Meyer, T. J., Electrocatalytic water oxidation with a copper(II) polypeptide complex. J Am Chem Soc 2013, 135 (6), 2048-51.

11 Garrido-Barros, P.; Funes-Ardoiz, I.; Drouet, S.; Benet-Buchholz, J.; Maseras, F.; Llobet, A., Redox Non-innocent Ligand Controls Water Oxidation Overpotential in a New Family of Mononuclear Cu-Based Efficient Catalysts. J Am Chem Soc 2015, 137 (21), 6758-6761.

12 Ghosh, T.; Ghosh, P.; Maayan, G., A Copper-Peptoid as a Highly Stable, Efficient, and Reusable Homogeneous Water Oxidation Electrocatalyst. Acs Catal 2018, 8 (11), 10631-10640.

13 Pap, J. S.; Szyrwiel, L.; Sranko, D.; Kerner, Z.; Setner, B.; Szewczuk, Z.; Malinka, W., Electrocatalytic water oxidation by $\mathrm{Cu}(\mathrm{II})$ complexes with branched peptides. Chem Commun (Camb) 2015, 51 (29), 6322-4.

14 Chen, F. F.; Wang, N.; Lei, H. T.; Guo, D. Y.; Liu, H. F.; Zhang, Z. Y.; Zhang, W.; Lai, W. Z.; Cao, R., Electrocatalytic Water Oxidation by a Water-Soluble Copper(II) 
Complex with a Copper-Bound Carbonate Group Acting as a Potential Proton Shuttle. Inorg Chem 2017, 56 (21), 13368-13375.

15 Yu, F. S.; Li, F.; Hu, J. X.; Bai, L. C.; Zhu, Y.; Sun, L. C., Electrocatalytic water oxidation by a macrocyclic $\mathrm{Cu}(\mathrm{II})$ complex in neutral phosphate buffer. Chem Commun 2016, 52 (68), 10377-10380.

16 Coggins, M. K.; Zhang, M. T.; Chen, Z.; Song, N.; Meyer, T. J., Single-site copper(II) water oxidation electrocatalysis: rate enhancements with $\mathrm{HPO}(4)(2)(-)$ as a proton acceptor at pH 8. Angew Chem Int Ed Engl 2014, 53 (45), 12226-30.

17 Kuilya, H.; Alam, N.; Sarma, D.; Choudhury, D.; Kalita, A., Ligand assisted electrocatalytic water oxidation by a copper(II) complex in neutral phosphate buffer. Chem Commun 2019, 55 (38), 5483-5486.

18 Liu, Y. J.; Han, Y. Z.; Zhang, Z. Y.; Zhang, W.; Lai, W. Z.; Wang, Y.; Cao, R., Low overpotential water oxidation at neutral $\mathrm{pH}$ catalyzed by a copper(ii) porphyrin. Chem Sci 2019, 10 (9), 2613-2622.

19 Su, X. J.; Gao, M.; Jiao, L.; Liao, R. Z.; Siegbahn, P. E.; Cheng, J. P.; Zhang, M. T., Electrocatalytic water oxidation by a dinuclear copper complex in a neutral aqueous solution. Angew Chem Int Ed Engl 2015, 54 (16), 4909-14.

$20 \mathrm{Su}$, X. J.; Zheng, C.; Hu, Q. Q.; Du, H. Y.; Liao, R. Z.; Zhang, M. T., Bimetallic cooperative effect on O-O bond formation: copper polypyridyl complexes as water oxidation catalyst. Dalton Trans 2018, 47 (26), 8670-8675.

21 Garrido-Barros, P.; Moonshiram, D.; Gil-Sepulcre, M.; Pelosin, P.; Gimbert-Surinach, C.; Benet-Buchholz, J.; Llobet, A., Redox Metal-Ligand Cooperativity Enables Robust and Efficient Water Oxidation Catalysis at Neutral $\mathrm{pH}$ with Macrocyclic Copper Complexes. J Am Chem Soc 2020, 142 (41), 17434-17446. 